\title{
Theoretical Study on Solubility from Pt Electrocatalyst and Reactivity in Electrolyte Environment of Pt Complex in PEFC
}

\author{
Takayoshi Ishimoto ${ }^{1}$ and Michihisa Koyama ${ }^{1,2}$ \\ ${ }^{1}$ INAMORI Frontier Research Center, Kyushu University, 744 Motooka, Nishi-ku, Fukuoka 819-0395, Japan \\ ${ }^{2}$ International Institute for Carbon-Neutral Energy Research, Kyushu University, 744 Motooka, Nishi-ku, Fukuoka 819-0395, Japan
}

Correspondence should be addressed to Takayoshi Ishimoto, ishimoto@ifrc.kyushu-u.ac.jp

and Michihisa Koyama, koyama@ifrc.kyushu-u.ac.jp

Received 30 March 2012; Accepted 8 May 2012

Academic Editor: Zhen-Bo Wang

Copyright (c) 2012 T. Ishimoto and M. Koyama. This is an open access article distributed under the Creative Commons Attribution License, which permits unrestricted use, distribution, and reproduction in any medium, provided the original work is properly cited.

\begin{abstract}
We theoretically analyzed the formation energy and solvation free energy of $\mathrm{Pt}(\mathrm{II})$ and $\mathrm{Pt}(\mathrm{IV})$ complexes with three types of ligands $\left(\mathrm{H}_{2} \mathrm{O}, \mathrm{OH}^{-}\right.$, and $\left.\mathrm{CF}_{3} \mathrm{SO}_{3}{ }^{-}\right)$in electrolyte environment under the low- and high-humidity conditions to study the Pt electrocatalyst degradation and dissolution mechanisms for polymer electrolyte fuel cell. To represent the low- and high-humidity conditions in perfluorosulfonic acid (PFSA) polymer electrolyte membrane, we controlled the dielectric constant based on the experimental result. We observed general tendencies that the formation energy becomes larger while the solvation free energy becomes smaller under the low-humidity condition. The degradation of Pt complex from Pt surface is indicated to be accelerated by the adsorption of the end group of PFSA polymer side chain, on the Pt surface by comparing the desorption energies of $\left[\mathrm{Pt}\left(\mathrm{H}_{2} \mathrm{O}\right)_{2}(\mathrm{OH})_{3}\left(\mathrm{CF}_{3} \mathrm{SO}_{3}\right)\right]$ and $\left[\mathrm{Pt}\left(\mathrm{H}_{2} \mathrm{O}\right)_{2}(\mathrm{OH})_{4}\right]$. The $\left[\mathrm{Pt}\left(\mathrm{H}_{2} \mathrm{O}\right)_{4}\right]^{2+}$ is not formed by the proton addition reaction between $\mathrm{Pt}$ complexes under the low-humidity condition of PFSA environment. From the analysis of possible reaction pathways of Pt complexes, we found the influence of humidity on the reactivity of Pt complex.
\end{abstract}

\section{Introduction}

Polymer electrolyte fuel cell (PEFC) has attracted much interest as a promising power source for automobiles and cogeneration systems because of its high-energy conversion efficiency with environmental benefits. For the practical long-term operation of PEFC, the durability of the membrane electrode assemble (MEA) is one of the main issues. PEFC catalysts in MEA typically consist of Pt nanoparticles with 2-3 nm diameter, which are dispersed on the surface of primary carbon particles of $20-50 \mathrm{~nm}$. The degradation of Pt electrocatalyst is particularly significant for the overall performance of MEA although the Pt-based alloys are usually utilized as electrocatalyst due to the electrochemical stability over a wide potential region in various fields. Iterative Pt dissolution and reprecipitation processes lead to the growth of Pt particles called Ostwald ripening, causing the degradation of the electrocatalytic activity.

Many studies have reported the loss of electrochemical surface area by the Pt dissolution and reprecipitation phenomena during the operation [1-15]. It is found that $\mathrm{Pt}$ dissolution depends on the voltage, acidity, and temperature. For example, Wang et al. reported the increasing of dissolved Pt concentration by the high electrostatic potential [15]. For the detailed understandings, Mitsushima et al. analyzed the solubility and the dissolution mechanism of $\mathrm{Pt}$ in acidic media at different temperature and $\mathrm{pH}$ [10]. They found high solubility of $\mathrm{Pt}$ at high temperature. In addition, Umeda et al. found the $\mathrm{Pt}(\mathrm{OH})_{4}$ formation for first step of Pt degradation in concentrated sulfuric acid by using rotating ringdisk electrode (RRDE) and electrochemical quartz crystal microbalance (EQCM) [8]. Based on these experimental studies, we have already analyzed the dissolved species in concentrated sulfuric acid as a first step to tackle the Pt dissolution and precipitation phenomena by using the density functional theory (DFT) calculation from an atomistic point of view [16]. We have found that the $\left[\mathrm{Pt}\left(\mathrm{H}_{2} \mathrm{O}\right)_{2}(\mathrm{OH})_{4}\right]$ and $\left[\mathrm{Pt}(\mathrm{OH})_{4}\right]^{2-}$ are important complexes for desorption from the Pt surface based on the desorption energy analysis. This 
theoretical analysis explained well the experimental observations for concentrated sulfuric acid, however, the behavior of $\mathrm{Pt}$ complex in perfluorosulfonic acid (PFSA) polymer electrolyte membrane, such as Nafion, remains unclear. Recently, there are some experimental studies analyzing the $\mathrm{Pt}$ dissolution in the PFSA environment [17-23]. The adsorption of PFSA polymer on Pt surface was studied by using a voltammetric fingerprinting approach and infrared reflection absorption spectroscopy [20, 21]. They clearly found the direct adsorption of sulfonate anions, which is an end group of PFSA polymer side chain, onto the Pt surface. Yoshida et al. clarified that the side chain end group of Nafion is acting as a ligand of six-coordinate Pt(IV) complex by using extended X-ray absorption fine structure (EXAFS) $[7,13]$. In addition, the dependence of the solubility of $\mathrm{Pt}$ complex in different PFSA polymer electrolyte was observed [19]. In addition, higher degradation under low humidity condition was observed [24-26]. The experimental results suggest that the interaction between Pt and PFSA polymer humidity are playing key roles in the degradation of Pt catalyst because the solubility of Pt complex becomes large with the existence of PFSA polymer electrolyte membrane. Those findings indicate that the stability and reactivity of $\mathrm{Pt}$ complexes under PFSA environment is different from our preceding results for the concentrated sulfuric acid [16]. One of the differences of concentrated sulfuric acid and PFSA environment is the dielectric property as well as the possible ligand, that is, sulfate anion.

In this study, we analyzed the Pt dissolution and precipitation phenomena under the low- and high-humidity PFSA conditions. We theoretically analyzed the solvation structures and thermodynamic stabilities of Pt complex in PFSA polymer assuming $\mathrm{H}_{2} \mathrm{O}, \mathrm{OH}^{-}$, and $\mathrm{CF}_{3} \mathrm{SO}_{3}{ }^{-}$as ligands. We also analyzed the desorption energy of $\mathrm{Pt}$ complex from $\mathrm{Pt}$ surface. The reactivity of $\mathrm{Pt}$ complex is discussed by comparing the results obtained for the different dielectric constants.

\section{Computational Details}

All calculations were performed under the generalized gradient approximation with Becke-88 exchange and LeeYang-Parr correlation functionals (BLYP) as implemented in the $\mathrm{DMol}^{3}$ package $[27,28]$. Double numerical atomic basis sets augmented with polarization function (DNP) were used to describe the valence electrons, and the core electrons were represented by effective core potentials (ECP). Solvent effects were estimated using the conductor-like screening model (COSMO). Table 1 shows the various dielectric constants to represent the surrounding condition of $\mathrm{Pt}$ complexes. Because the experimental result of dielectric constant in PFSA at working temperature is unavailable, we used the dielectric constants of 5 and 20 reported for low- and highhumidity condition of Nafion membrane at 303.15 K [29]. Those values for bulk properties of Nafion membrane might be different from the local dielectric properties around $\mathrm{Pt}$ catalyst because of the water formation as results of cathodic reaction especially at high current density operation. We therefore set the dielectric constant of 61.0 for water at 353.15 [30] as one extreme. Full geometry optimization
TABLE 1: Values of dielectric constant with various condition and temperature.

\begin{tabular}{lccc}
\hline $\begin{array}{l}\text { Dielectric } \\
\text { constant }(\varepsilon)\end{array}$ & Condition & Temperature $(K)$ & Reference \\
\hline 5 & $\begin{array}{c}\text { Nafion membrane } \\
\text { (low humidity) }\end{array}$ & 303.15 & {$[29]$} \\
20 & $\begin{array}{c}\text { Nafion membrane } \\
\text { (high humidity) } \\
\text { water solution } \\
\text { (locally high } \\
\text { humidity) }\end{array}$ & 303.15 & {$[29]$} \\
\hline
\end{tabular}

was performed for each system by using these dielectric constants. All thermodynamic data have been evaluated for a typical working temperature of $353.15 \mathrm{~K}$.

We used four- and six-coordinated $\mathrm{Pt}(\mathrm{II})$ and $\mathrm{Pt}(\mathrm{IV})$ complexes with three types of ligands $\left(\mathrm{H}_{2} \mathrm{O}, \mathrm{OH}^{-}\right.$, and $\mathrm{CF}_{3} \mathrm{SO}_{3}{ }^{-}$) as models of dissolved $\mathrm{Pt}$ species in PFSA environment for analyzing the formation energy and Gibbs free energy. Note that we consider $\mathrm{OH}^{-}$as a ligand even in the acidic PEFC condition assuming that $\mathrm{OH}^{-}$formed on $\mathrm{Pt}$ surface could play an important role in the formation of intermediate species for dissolution $[6,31-33]$. The $\mathrm{CF}_{3} \mathrm{SO}_{3}{ }^{-}$ is a model compound of end group of PFSA polymer side chain.

\section{Results and Discussion}

3.1. Analysis of Dissolved Pt Complexes in Various Dielectric Constants. We first analyzed the formation energy $\left(\Delta E_{f}\right)$ and solvation free energy $\left(\Delta G_{\text {solv }}\right)$ of the four- and six-coordinate $\mathrm{Pt}(\mathrm{II})$ and $\mathrm{Pt}(\mathrm{IV})$ complexes as the dissolved species under various dielectric constant. The optimized structures of $\mathrm{Pt}(\mathrm{II})$ and $\mathrm{Pt}(\mathrm{IV})$ complexes $(\varepsilon=5.0)$ with three ligands $\left(\mathrm{H}_{2} \mathrm{O}, \mathrm{OH}^{-}\right.$, and $\left.\mathrm{CF}_{3} \mathrm{SO}_{3}{ }^{-}\right)$are shown in Figures 1 and 2, respectively. Two coordination configurations of $\mathrm{CF}_{3} \mathrm{SO}_{3}{ }^{-}$is not considered in present calculation due to the low stability [34]. Four- and six-coordinate $\mathrm{Pt}(\mathrm{II})$ and $\mathrm{Pt}(\mathrm{IV})$ complexes were square and octahedral structures, respectively. Oxygen atoms are coordinating to $\mathrm{Pt}$ in all optimized structures. The $\Delta E_{f}$ of $\mathrm{Pt}(\mathrm{II})$ and $\mathrm{Pt}(\mathrm{IV})$ complexes were evaluated by the following equations,

$$
\begin{aligned}
\Delta E_{f}= & E\left(\left[\mathrm{Pt}\left(\mathrm{H}_{2} \mathrm{O}\right)_{m}(\mathrm{~L})_{n}\right]^{2-n}\right) \\
& -\left\{E\left(\mathrm{Pt}^{2+}\right)+m E\left(\mathrm{H}_{2} \mathrm{O}\right)+n E(\mathrm{~L})\right\}(m+n=4), \\
\Delta E_{f}= & E\left(\left[\mathrm{Pt}\left(\mathrm{H}_{2} \mathrm{O}\right)_{m}(\mathrm{~L})_{n}\right]^{4-n}\right) \\
& -\left\{E\left(\mathrm{Pt}^{4+}\right)+m E\left(\mathrm{H}_{2} \mathrm{O}\right)+n E(\mathrm{~L})\right\}(m+n=6) .
\end{aligned}
$$

Here $\mathrm{L}$ stands for $\mathrm{OH}^{-}$or $\mathrm{CF}_{3} \mathrm{SO}_{3}{ }^{-}$. To evaluate the stability of Pt complex in water solution or PFSA polymer electrolyte membrane, the $\Delta G_{\text {solv }}$ was calculated by following equation:

$$
G_{\text {solv }}=G(\text { COSMO })-G(\text { Gas }) .
$$




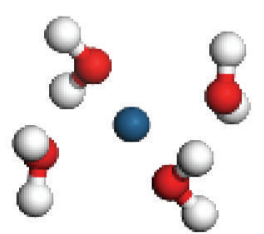

(1) $\left[\mathrm{Pt}\left(\mathrm{H}_{2} \mathrm{O}\right)_{4}\right]^{2+}$

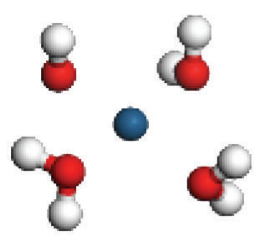

(2) $\left[\mathrm{Pt}\left(\mathrm{H}_{2} \mathrm{O}\right)_{3}(\mathrm{OH})\right]^{+}$

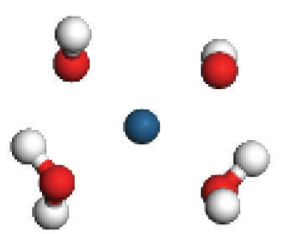

(3) $\left[\mathrm{Pt}\left(\mathrm{H}_{2} \mathrm{O}\right)_{2}(\mathrm{OH})_{2}\right]$

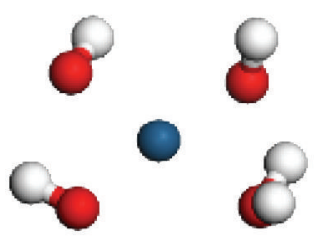

(4) $\left[\mathrm{Pt}\left(\mathrm{H}_{2} \mathrm{O}\right)(\mathrm{OH})_{3}\right]^{-}$

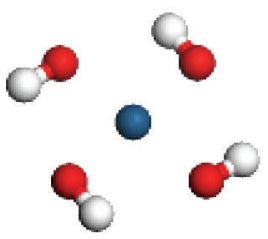

(5) $\left[\mathrm{Pt}(\mathrm{OH})_{4}\right]^{-}$

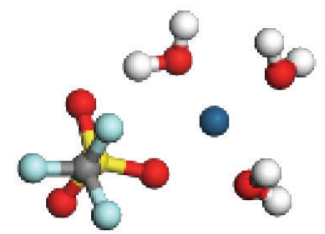

(6) $\left[\mathrm{Pt}\left(\mathrm{H}_{2} \mathrm{O}\right)_{5}\left(\mathrm{CF}_{3} \mathrm{SO}_{3}\right)\right]^{+}$

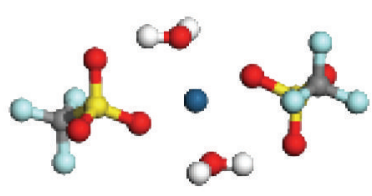

(7) $\left[\mathrm{Pt}\left(\mathrm{H}_{2} \mathrm{O}\right)_{2}\left(\mathrm{CF}_{3} \mathrm{SO}_{3}\right)_{2}\right]$

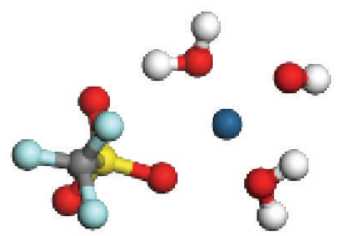

(8) $\left[\mathrm{Pt}\left(\mathrm{H}_{2} \mathrm{O}\right)_{2}(\mathrm{OH})\left(\mathrm{CF}_{3} \mathrm{SO}_{3}\right)\right]$

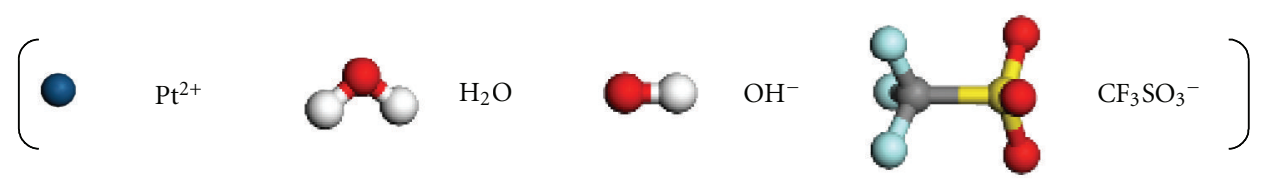

Figure 1: Optimized structures of four-coordinate $\mathrm{Pt}(\mathrm{II})$ complexes with three types of ligands $\left(\mathrm{H}_{2} \mathrm{O}, \mathrm{OH}^{-}\right.$, and $\left.\mathrm{CF}_{3} \mathrm{SO}_{3}{ }^{-}\right)$at $\varepsilon=5.0$.

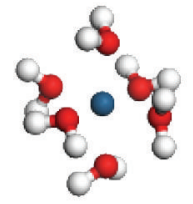

(1) $\left[\mathrm{Pt}\left(\mathrm{H}_{2} \mathrm{O}\right)_{6}\right]^{4+}$

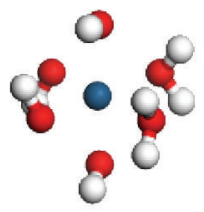

(5) $\left[\mathrm{Pt}\left(\mathrm{H}_{2} \mathrm{O}\right)_{2}(\mathrm{OH})_{4}\right]$

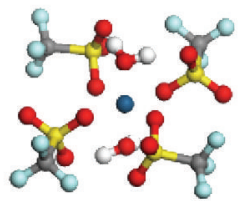

(9) $\left[\mathrm{Pt}\left(\mathrm{H}_{2} \mathrm{O}\right)_{2}\left(\mathrm{CF}_{3} \mathrm{SO}_{3}\right)_{4}\right]$

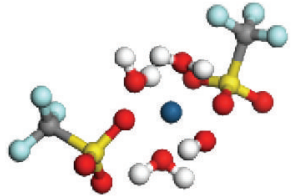

(13) $\left[\mathrm{Pt}\left(\mathrm{H}_{2} \mathrm{O}\right)_{3}(\mathrm{OH})\left(\mathrm{CF}_{3} \mathrm{SO}_{3}\right) 2\right]^{+}$

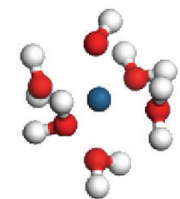

(2) $\left[\mathrm{Pt}\left(\mathrm{H}_{2} \mathrm{O}\right)_{5}(\mathrm{OH})\right]^{3+}$

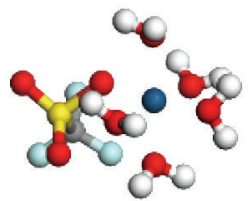

(6) $\left[\mathrm{Pt}\left(\mathrm{H}_{2} \mathrm{O}\right)_{5}\left(\mathrm{CF}_{3} \mathrm{SO}_{3}\right)\right]^{3+}$

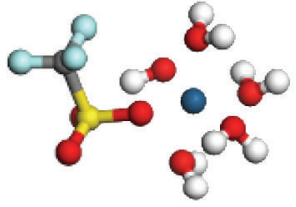

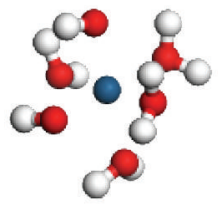

(3) $\left[\mathrm{Pt}\left(\mathrm{H}_{2} \mathrm{O}\right)_{4}(\mathrm{OH})_{2}\right]^{2+}$

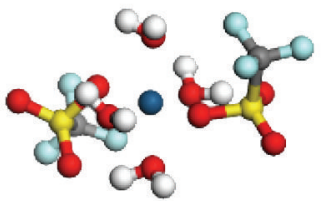

(7) $\left[\mathrm{Pt}\left(\mathrm{H}_{2} \mathrm{O}\right)_{4}\left(\mathrm{CF}_{3} \mathrm{SO}_{3}\right)_{2}\right]^{2+}$

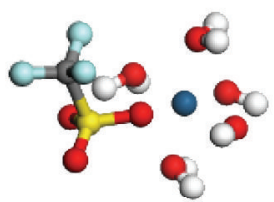

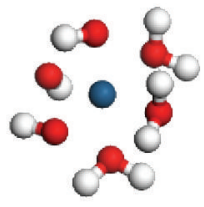

(4) $\left[\mathrm{Pt}\left(\mathrm{H}_{2} \mathrm{O}\right)_{3}(\mathrm{OH})_{3}\right]^{+}$

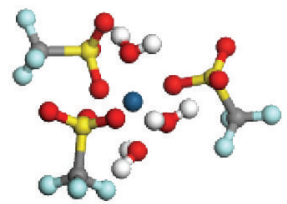

(8) $\left[\mathrm{Pt}\left(\mathrm{H}_{2} \mathrm{O}\right)_{3}\left(\mathrm{CF}_{3} \mathrm{SO}_{3}\right)_{3}\right]^{+}$

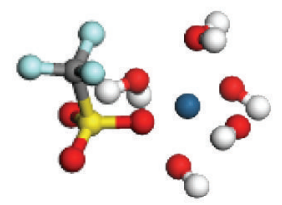

(10) $\left[\mathrm{Pt}\left(\mathrm{H}_{2} \mathrm{O}\right)_{4}(\mathrm{OH})\left(\mathrm{CF}_{3} \mathrm{SO}_{3}\right)\right]^{2+}\left(\right.$ 11) $\left[\mathrm{Pt}\left(\mathrm{H}_{2} \mathrm{O}\right)_{3}(\mathrm{OH})_{2}\left(\mathrm{CF}_{3} \mathrm{SO}_{3}\right)\right]^{2+}\left(\right.$ 12) $\left[\mathrm{Pt}\left(\mathrm{H}_{2} \mathrm{O}\right)_{2}(\mathrm{OH})_{3}\left(\mathrm{CF}_{3} \mathrm{SO}_{3}\right)\right]$
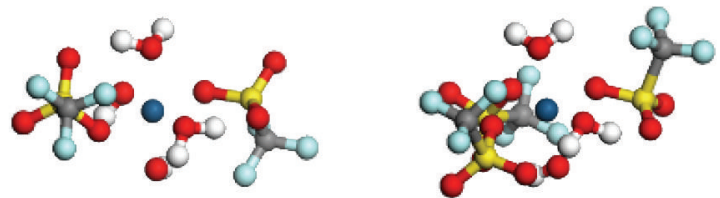

(15) $\left[\mathrm{Pt}\left(\mathrm{H}_{2} \mathrm{O}\right)_{2}(\mathrm{OH})\left(\mathrm{CF}_{3} \mathrm{SO}_{3}\right)_{3}\right]$

$$
\left(\begin{array}{lllllll}
-\mathrm{Pt}^{4+} & \mathrm{HO} & \mathrm{H} \mathrm{O} & \mathrm{OO} & \mathrm{OH}^{-} & \mathrm{g}=8 & \mathrm{CF}_{3} \mathrm{SO}_{3}^{-}
\end{array}\right)
$$

FIgURE 2: Optimized structures of six-coordinate $\mathrm{Pt}(\mathrm{IV})$ complexes with three types of ligands $\left(\mathrm{H}_{2} \mathrm{O}, \mathrm{OH}^{-}\right.$, and $\left.\mathrm{CF}_{3} \mathrm{SO}_{3}{ }^{-}\right)$at $\varepsilon=5.0$. 
TABLE 2: Formation energy $\left(\Delta E_{f}\right)$ and solvation free energy $\left(\Delta G_{\text {solv }}\right)$ of $\mathrm{Pt}(\mathrm{II})$ complexes with various dielectric constants. Unit is $\mathrm{kJ} / \mathrm{mol}$.

\begin{tabular}{|c|c|c|c|c|c|c|}
\hline \multirow{2}{*}{$\begin{array}{l}\mathrm{Pt}(\mathrm{II}) \text { complex } \\
\text { dielectric constant }(\varepsilon)\end{array}$} & \multicolumn{3}{|c|}{ Formation energy $\left(\Delta E_{f}\right)$} & \multicolumn{3}{|c|}{ Solvation free energy $\left(\Delta G_{\text {solv }}\right)$} \\
\hline & 5.0 & 20.0 & 61.0 & 5.0 & 20.0 & 61.0 \\
\hline (1) $\left[\mathrm{Pt}\left(\mathrm{H}_{2} \mathrm{O}\right)_{4}\right]^{2+}$ & -628.6 & -506.4 & -479.6 & -670.9 & -858.8 & -904.8 \\
\hline (2) $\left[\mathrm{Pt}\left(\mathrm{H}_{2} \mathrm{O}\right)_{3}(\mathrm{OH})\right]^{+}$ & -1162.6 & -807.3 & -799.3 & -226.0 & -296.3 & -314.3 \\
\hline (3) $\left[\mathrm{Pt}\left(\mathrm{H}_{2} \mathrm{O}\right)_{2}(\mathrm{OH})_{2}\right]$ & -1543.8 & -1072.2 & -1031.6 & -58.6 & -85.8 & -93.7 \\
\hline (4) $\left[\mathrm{Pt}\left(\mathrm{H}_{2} \mathrm{O}\right)(\mathrm{OH})_{3}\right]^{-}$ & -1752.3 & -1250.5 & -1206.5 & -233.9 & -312.6 & -332.7 \\
\hline (5) $\left[\mathrm{Pt}(\mathrm{OH})_{4}\right]^{2-}$ & -1830.1 & -1386.9 & -1348.0 & -714.8 & -920.7 & -973.0 \\
\hline (6) $\left[\mathrm{Pt}\left(\mathrm{H}_{2} \mathrm{O}\right)_{3}\left(\mathrm{CF}_{3} \mathrm{SO}_{3}\right)\right]^{+}$ & -837.8 & -529.8 & -497.6 & -268.7 & -373.3 & -402.6 \\
\hline (7) $\left[\mathrm{Pt}\left(\mathrm{H}_{2} \mathrm{O}\right)_{2}\left(\mathrm{CF}_{3} \mathrm{SO}_{3}\right)_{2}\right]$ & -957.5 & -563.7 & -533.6 & -69.9 & -97.9 & -105.9 \\
\hline (8) $\left[\mathrm{Pt}\left(\mathrm{H}_{2} \mathrm{O}\right)_{2}(\mathrm{OH})\left(\mathrm{CF}_{3} \mathrm{SO}_{3}\right)\right]$ & -1260.1 & -837.8 & -802.3 & -71.6 & -104.6 & -112.6 \\
\hline
\end{tabular}

The $G(\mathrm{COSMO})$ and $G(\mathrm{Gas})$ indicate the free energy for the solvated and gas phases of the optimized geometry, respectively. The $\Delta E_{f}$ of $\mathrm{Pt}(\mathrm{II})$ complexes are summarized in Table 2. The $\Delta E_{f}$ and $\Delta G_{\text {solv }}$ of $\left[\mathrm{Pt}\left(\mathrm{H}_{2} \mathrm{O}\right)_{4}\right]^{2+}$ at $\varepsilon=5.0$ are -628.6 and $-670.9 \mathrm{~kJ} / \mathrm{mol}$, respectively. By the substitution of $\mathrm{OH}^{-}$for $\mathrm{H}_{2} \mathrm{O}$, the $\Delta E_{f}$ of $\left[\mathrm{Pt}\left(\mathrm{H}_{2} \mathrm{O}\right)_{3}(\mathrm{OH})\right]^{+}$became stable largely by about $530 \mathrm{~kJ} / \mathrm{mol}$ in comparison with $\left[\mathrm{Pt}\left(\mathrm{H}_{2} \mathrm{O}\right)_{4}\right]^{2+}$. On the contrary, modest stabilization was observed when the $\mathrm{H}_{2} \mathrm{O}$ was substituted with $\mathrm{CF}_{3} \mathrm{SO}_{3}{ }^{-}$. When we compare the $\Delta G_{\text {solv }}$, we found that the charged species shows large solvation energy. The $\Delta G_{\text {solv }}$ 's of $\mathrm{Pt}(\mathrm{II})$ complexes $((\mathbf{1})$ and (5)) show higher stability than that of singly charged complexes $((2),(4)$, and (6)). The neutral $\mathrm{Pt}(\mathrm{II})$ complexes ((3), (7), and (8)) had less gain in the solvation. We then analyzed the $\Delta E_{f}$ and $\Delta G_{\text {solv }}$ under high-humidity condition by comparing the results for the dielectric constants of 5.0 and 20.0. The $\Delta E_{f}$ and $\Delta G_{\text {solv }}$ of $\left[\mathrm{Pt}\left(\mathrm{H}_{2} \mathrm{O}\right)_{4}\right]^{2+}$ are -506.4 and $-858.8 \mathrm{~kJ} / \mathrm{mol}$, respectively, at $\varepsilon=20.0$. The $\Delta E_{f}$ becomes larger, that is, the complex becomes unstable, when the dielectric constant becomes large. On the other hand, the $\Delta G_{\text {solv }}$ becomes smaller indicating the larger solvation gain. This means that the humidity unstabilizes the complex while making its solvation favorable thermodynamically. We also analyzed the $\Delta E_{f}$ and $\Delta G_{\text {solv }}$ of $\mathrm{Pt}(\mathrm{II})$ and $\mathrm{Pt}(\mathrm{IV})$ complexes in water solution at $353.15 \mathrm{~K}$ setting $\varepsilon=61.0$ to see the properties of extremely humidified electrocatalyst at local scale. The $\Delta E$ 's of $\mathrm{Pt}$ complexes in water solution are larger than those in PFSA. On the contrary, the $\Delta G_{\text {solv }}$ 's of Pt complex in water solution are smaller as observed in the comparison of results obtained for $\varepsilon=5.0$ and 20.0. Considering that the dielectric constants of water at 298.15 and 353.15 are 78.5 and 61.0, respectively, the actual properties in PFSA environment under low- and high-humidity at $353.15 \mathrm{~K}$ can be estimated by extrapolating and interpolating the results obtained for dielectric constant at $303.15 \mathrm{~K}$, that is, $\varepsilon=5.0$ and 20.0 , respectively. This means that the lower temperature has thermodynamically the effect on the Pt degradation similar to the higher humidity.

In case of six-coordinate $\mathrm{Pt}(\mathrm{IV})$ complexes (Table 3 ), at $\varepsilon$ $=5.0$, the $\Delta E(-2571.7 \mathrm{~kJ} / \mathrm{mol})$ and $\Delta G_{\text {solv }}(-2407.6 \mathrm{~kJ} / \mathrm{mol})$ of $\left[\mathrm{Pt}\left(\mathrm{H}_{2} \mathrm{O}\right)_{6}\right]^{4+}$ are much more stable than those of $\left[\mathrm{Pt}\left(\mathrm{H}_{2} \mathrm{O}\right)_{4}\right]^{2+}$. We observed the dependencies of $\Delta E_{f}$ and $\Delta G_{\text {solv }}$ on dielectric constant similar to that observed for the $\mathrm{Pt}(\mathrm{II})$ complexes.
3.2. Desorption Energy of Pt Complex from Pt Surface. We next focused on the desorption energy $\left(\Delta E_{\text {des }}\right)$ of $\operatorname{Pt}($ II $)$ and $\mathrm{Pt}(\mathrm{IV})$ complexes from the Pt surface to estimate the initial dissolved species. We used a simple $\mathrm{Pt}_{4}$ cluster as a $\mathrm{Pt}$ surface model to estimate the $\Delta E_{\text {des }}$ of $\mathrm{Pt}(\mathrm{II})$ and $\mathrm{Pt}(\mathrm{IV})$ complexes from Pt surface. Although the $\mathrm{Pt}_{4}$ cluster is small to represent the Pt surface, the useful results for Pt surface stability and reactivity are already reported by using $\mathrm{Pt}_{4}$ cluster $[35,36]$. We assumed the $\mathrm{OH}^{-}$and $\mathrm{CF}_{3} \mathrm{SO}_{3}{ }^{-}$adsorption on the $\mathrm{Pt}$ surface because these species are proposed as the adsorption molecules on the Pt surface.

$$
\begin{aligned}
{\left[\mathrm{Pt}_{4}(\mathrm{~L})_{n}\right]^{2-n} } & +\left(\mathrm{H}_{2} \mathrm{O}\right)_{m} \longrightarrow \mathrm{Pt}_{3} \\
& +\left[\mathrm{Pt}\left(\mathrm{H}_{2} \mathrm{O}\right)_{m}(\mathrm{~L})_{n}\right]^{2-n}(m+n=4) \\
{\left[\mathrm{Pt}_{4}(\mathrm{~L})_{n}\right]^{4-n} } & +\left(\mathrm{H}_{2} \mathrm{O}\right)_{m} \longrightarrow \mathrm{Pt}_{3} \\
& +\left[\mathrm{Pt}\left(\mathrm{H}_{2} \mathrm{O}\right)_{m}(\mathrm{~L})_{n}\right]^{4-n}(m+n=6)
\end{aligned}
$$

Here, $\mathrm{L}$ stands for $\mathrm{OH}^{-}$or $\mathrm{CF}_{3} \mathrm{SO}_{3}{ }^{-}$. Tables 4 and 5 summarize the $\Delta E_{\text {des }}$ of $\mathrm{Pt}(\mathrm{II})$ and $\mathrm{Pt}(\mathrm{IV})$ complexes from the Pt surface model. The $\Delta E_{\text {des }}$ of $\mathrm{Pt}(\mathrm{II})$ and $\mathrm{Pt}(\mathrm{IV})$ complexes were evaluated by the following equations

$$
\begin{aligned}
\Delta E_{\mathrm{des}}= & \left\{E\left(\mathrm{Pt}_{3}\right)+E\left(\left[\mathrm{Pt}\left(\mathrm{H}_{2} \mathrm{O}\right)_{m}(\mathrm{~L})_{n}\right]^{2-n}\right)\right\} \\
& -\left\{E\left(\left[\mathrm{Pt}_{4}(\mathrm{~L})_{n}\right]^{2-n}\right)+E\left(\left(\mathrm{H}_{2} \mathrm{O}\right)_{m}\right)\right\}(m+n=4) \\
\Delta E_{\mathrm{des}}= & \left\{E\left(\mathrm{Pt}_{3}\right)+E\left(\left[\mathrm{Pt}\left(\mathrm{H}_{2} \mathrm{O}\right)_{m}(\mathrm{~L})_{n}\right]^{4-n}\right)\right\} \\
& -\left\{E\left(\left[\mathrm{Pt}_{4}(\mathrm{~L})_{n}\right]^{4-n}\right)+E\left(\left(\mathrm{H}_{2} \mathrm{O}\right)_{m}\right)\right\}(m+n=6)
\end{aligned}
$$

The negative value of $\Delta E_{\text {des }}$ indicates that the desorption of $\mathrm{Pt}$ complex to the solvent from the Pt surface is favorable. For $\mathrm{Pt}$ (II) complexes, the $\Delta E_{\text {des }}$ becomes larger as the dielectric constant becomes larger. Although most of $\mathrm{Pt}(\mathrm{II})$ complexes have positive desorption energies, only $\left[\mathrm{Pt}(\mathrm{OH})_{4}\right]^{2-}$ is found as a candidate for initial dissolution species from the $\mathrm{Pt}$ surface. The desorption of $\left[\mathrm{Pt}(\mathrm{OH})_{4}\right]^{2-}$ at $\varepsilon=5.0$ is small in comparison with high humidity $(\varepsilon=20.0)$ and water $(\varepsilon$ $=61.0$ ) environments. Also we note that higher temperature corresponds to lower dielectric constant. We thus conclude 
TABLE 3: Formation energy $\left(\Delta E_{f}\right)$ and solvation free energy $\left(\Delta G_{\text {solv }}\right)$ of $\operatorname{Pt}(\mathrm{IV})$ complexes with various dielectric constants. Unit is kJ/mol.

\begin{tabular}{|c|c|c|c|c|c|c|}
\hline \multirow{2}{*}{$\begin{array}{l}\mathrm{Pt}(\mathrm{IV}) \text { complex } \\
\text { dielectric constant }(\varepsilon)\end{array}$} & \multicolumn{3}{|c|}{ Formation energy $\left(\Delta E_{f}\right)$} & \multicolumn{3}{|c|}{ Solvation free energy $\left(\Delta G_{\text {solv }}\right)$} \\
\hline & 5.0 & 20.0 & 61.0 & 5.0 & 20.0 & 61.0 \\
\hline (1) $\left[\mathrm{Pt}\left(\mathrm{H}_{2} \mathrm{O}\right)_{6}\right]^{4+}$ & -2571.7 & -1940.6 & -1790.8 & -2407.6 & -3081.4 & -3246.3 \\
\hline (2) $\left[\mathrm{Pt}\left(\mathrm{H}_{2} \mathrm{O}\right)_{5}(\mathrm{OH})\right]^{3+}$ & -3472.3 & -2480.9 & -2254.9 & -1391.9 & -1784.5 & -1881.2 \\
\hline (3) $\left[\mathrm{Pt}\left(\mathrm{H}_{2} \mathrm{O}\right)_{4}(\mathrm{OH})_{2}\right]^{2+}$ & -4193.0 & -2944.1 & -2640.7 & -663.7 & -853.7 & -901.0 \\
\hline (4) $\left[\mathrm{Pt}\left(\mathrm{H}_{2} \mathrm{O}\right)_{3}(\mathrm{OH})_{3}\right]^{+}$ & -4761.3 & -3320.4 & -2961.7 & -232.3 & -317.2 & -338.1 \\
\hline (5) $\left[\mathrm{Pt}\left(\mathrm{H}_{2} \mathrm{O}\right)_{2}(\mathrm{OH})_{4}\right]$ & -5145.5 & -3589.5 & -3213.2 & -82.9 & -127.2 & -137.3 \\
\hline (6) $\left[\mathrm{Pt}\left(\mathrm{H}_{2} \mathrm{O}\right)_{5}\left(\mathrm{CF}_{3} \mathrm{SO}_{3}\right)\right]^{3+}$ & -3074.3 & -2099.2 & -1878.6 & -1356.8 & -1825.9 & -1943.1 \\
\hline (7) $\left[\mathrm{Pt}\left(\mathrm{H}_{2} \mathrm{O}\right)_{4}\left(\mathrm{CF}_{3} \mathrm{SO}_{3}\right)_{2}\right]^{2+}$ & -3422.9 & -2234.8 & -1953.6 & -654.1 & -882.2 & -939.5 \\
\hline (8) $\left[\mathrm{Pt}\left(\mathrm{H}_{2} \mathrm{O}\right)_{3}\left(\mathrm{CF}_{3} \mathrm{SO}_{3}\right)_{3}\right]^{+}$ & -3681.1 & -2325.6 & -2010.1 & -223.5 & -309.3 & -331.5 \\
\hline (9) $\left[\mathrm{Pt}\left(\mathrm{H}_{2} \mathrm{O}\right)_{2}\left(\mathrm{CF}_{3} \mathrm{SO}_{3}\right)_{4}\right]$ & -3808.4 & -2382.5 & -2040.6 & -57.8 & -82.4 & -88.7 \\
\hline (10) $\left[\mathrm{Pt}\left(\mathrm{H}_{2} \mathrm{O}\right)_{4}(\mathrm{OH})\left(\mathrm{CF}_{3} \mathrm{SO}_{3}\right)\right]^{2+}$ & -3801.2 & -2594.7 & -2295.5 & -695.5 & -929.1 & -999.8 \\
\hline (11) $\left[\mathrm{Pt}\left(\mathrm{H}_{2} \mathrm{O}\right)_{3}(\mathrm{OH})_{2}\left(\mathrm{CF}_{3} \mathrm{SO}_{3}\right)\right]^{+}$ & -4362.9 & -2960.9 & -2618.1 & -263.7 & -361.2 & -360.3 \\
\hline (12) $\left[\mathrm{Pt}\left(\mathrm{H}_{2} \mathrm{O}\right)_{2}(\mathrm{OH})_{3}\left(\mathrm{CF}_{3} \mathrm{SO}_{3}\right)\right]$ & -4874.7 & -3347.2 & -2976.0 & -74.9 & -105.9 & -113.8 \\
\hline (13) $\left[\mathrm{Pt}\left(\mathrm{H}_{2} \mathrm{O}\right)_{3}(\mathrm{OH})\left(\mathrm{CF}_{3} \mathrm{SO}_{3}\right)_{2}\right]^{+}$ & -4044.8 & -2678.8 & -2334.0 & -241.9 & -328.1 & -351.1 \\
\hline (14) $\left[\mathrm{Pt}\left(\mathrm{H}_{2} \mathrm{O}\right)_{2}(\mathrm{OH})_{2}\left(\mathrm{CF}_{3} \mathrm{SO}_{3}\right)_{2}\right]$ & -4540.3 & -3036.6 & -2670.0 & -68.6 & -93.7 & -101.7 \\
\hline (15) $\left[\mathrm{Pt}\left(\mathrm{H}_{2} \mathrm{O}\right)_{2}(\mathrm{OH})\left(\mathrm{CF}_{3} \mathrm{SO}_{3}\right)_{3}\right]$ & -4189.2 & -2736.6 & -2345.3 & -71.6 & -103.4 & -112.2 \\
\hline
\end{tabular}

TABle 4: Desorption energy $\left(\Delta E_{\mathrm{des}}\right)$ of $\mathrm{Pt}(\mathrm{II})$ complexes from $\mathrm{Pt}$ surface with various dielectric constants. Unit is $\mathrm{kJ} / \mathrm{mol}$.

\begin{tabular}{lccc}
\hline & 5.0 & 20.0 & 61.0 \\
\hline$(\mathbf{1})\left[\mathrm{Pt}\left(\mathrm{H}_{2} \mathrm{O}\right)_{4}\right]^{2+}$ & 126.0 & 162.0 & 172.8 \\
$(\mathbf{2})\left[\mathrm{Pt}\left(\mathrm{H}_{2} \mathrm{O}\right)_{3}(\mathrm{OH})\right]^{+}$ & 138.5 & 157.4 & 164.5 \\
$(3)\left[\mathrm{Pt}\left(\mathrm{H}_{2} \mathrm{O}\right)_{2}(\mathrm{OH})_{2}\right]$ & 108.4 & 127.2 & 134.3 \\
$(4)\left[\mathrm{Pt}\left(\mathrm{H}_{2} \mathrm{O}\right)(\mathrm{OH})_{3}\right]^{-}$ & 51.1 & 51.9 & 54.8 \\
$(\mathbf{5})\left[\mathrm{Pt}(\mathrm{OH})_{4}\right]^{2-}$ & -73.7 & -60.3 & -55.7 \\
$(\mathbf{6})\left[\mathrm{Pt}\left(\mathrm{H}_{2} \mathrm{O}\right)_{3}\left(\mathrm{CF}_{3} \mathrm{SO}_{3}\right)\right]^{+}$ & 154.8 & 190.4 & 186.2 \\
$(\mathbf{7})\left[\mathrm{Pt}\left(\mathrm{H}_{2} \mathrm{O}\right)_{2}\left(\mathrm{CF}_{3} \mathrm{SO}_{3}\right)_{2}\right]$ & 177.4 & 196.3 & 206.3 \\
$(\mathbf{8})\left[\mathrm{Pt}\left(\mathrm{H}_{2} \mathrm{O}\right)_{2}(\mathrm{OH})\left(\mathrm{CF}_{3} \mathrm{SO}_{3}\right)\right]$ & 122.2 & 124.3 & 147.3 \\
\hline
\end{tabular}

higher dissolution of $\mathrm{Pt}$ under low-humidity condition at high temperature.

On the other hand, we have found two possible $\mathrm{Pt}(\mathrm{IV})$ complexes, $\left[\mathrm{Pt}\left(\mathrm{H}_{2} \mathrm{O}\right)_{2}(\mathrm{OH})_{4}\right]$ and $\left[\mathrm{Pt}\left(\mathrm{H}_{2} \mathrm{O}\right)_{2}(\mathrm{OH})_{3}\right.$ $\left.\left(\mathrm{CF}_{3} \mathrm{SO}_{3}\right)\right]$, for the desorption from Pt surface. The $\Delta E_{\text {des }}$ of $\left[\mathrm{Pt}\left(\mathrm{H}_{2} \mathrm{O}\right)_{2}(\mathrm{OH})_{3}\left(\mathrm{CF}_{3} \mathrm{SO}_{3}\right)\right]$ is about $3 \mathrm{~kJ} / \mathrm{mol}$ smaller than that of $\left[\mathrm{Pt}\left(\mathrm{H}_{2} \mathrm{O}\right)_{2}(\mathrm{OH})_{4}\right]$. This result indicates that the desorption of Pt complex from Pt surface will be accelerated by the adsorption of end group of PFSA polymer side chain on the Pt surface, which is in agreement with the experimental observation [19]. The $\Delta E_{\text {des }}$ of $\left[\mathrm{Pt}\left(\mathrm{H}_{2} \mathrm{O}\right)_{2}(\mathrm{OH})_{4}\right]$ and $\left[\mathrm{Pt}\left(\mathrm{H}_{2} \mathrm{O}\right)_{2}(\mathrm{OH})_{3}\left(\mathrm{CF}_{3} \mathrm{SO}_{3}\right)\right]$ complexes become larger when the dielectric constant becomes larger. In addition, the $\Delta E_{\text {des }}$ of $\left[\mathrm{Pt}\left(\mathrm{H}_{2} \mathrm{O}\right)_{3}(\mathrm{OH})_{3}\right]^{+}$becomes close to zero at $\varepsilon=5.0$. This result indicates that the $\left[\mathrm{Pt}\left(\mathrm{H}_{2} \mathrm{O}\right)_{3}(\mathrm{OH})_{3}\right]^{+}$complex would dissolve from Pt surface in PFSA environment under lowhumidity condition at high temperature during the PEFC operation.

3.3. Structural Changes in Various Dielectric Environments. We then analyzed the geometrical parameters of selected
Table 5: Desorption energy $\left(\Delta E_{\text {des }}\right)$ of $\mathrm{Pt}(\mathrm{IV})$ complexes from $\mathrm{Pt}$ surface with various dielectric constants. Unit is $\mathrm{kJ} / \mathrm{mol}$.

\begin{tabular}{lccc}
\hline & 5.0 & 20.0 & 61.0 \\
\hline$(\mathbf{1})\left[\mathrm{Pt}\left(\mathrm{H}_{2} \mathrm{O}\right)_{6}\right]^{4+}$ & 58.2 & 138.5 & 177.9 \\
$(\mathbf{2})\left[\mathrm{Pt}\left(\mathrm{H}_{2} \mathrm{O}\right)_{5}(\mathrm{OH})\right]^{3+}$ & 51.1 & 144.0 & 154.8 \\
$(\mathbf{3})\left[\mathrm{Pt}\left(\mathrm{H}_{2} \mathrm{O}\right)_{4}(\mathrm{OH})_{2}\right]^{2+}$ & 47.3 & 97.1 & 114.2 \\
$(\mathbf{4})\left[\mathrm{Pt}\left(\mathrm{H}_{2} \mathrm{O}\right)_{3}(\mathrm{OH})_{3}\right]^{+}$ & 2.9 & 30.1 & 50.6 \\
$(\mathbf{5})\left[\mathrm{Pt}\left(\mathrm{H}_{2} \mathrm{O}\right)_{2}(\mathrm{OH})_{4}\right]$ & -69.1 & -64.0 & -60.7 \\
$(\mathbf{6})\left[\mathrm{Pt}\left(\mathrm{H}_{2} \mathrm{O}\right)_{5}\left(\mathrm{CF}_{3} \mathrm{SO}_{3}\right)\right]^{3+}$ & 72.0 & 191.7 & 216.8 \\
(7) $\left[\mathrm{Pt}\left(\mathrm{H}_{2} \mathrm{O}\right)_{4}\left(\mathrm{CF}_{3} \mathrm{SO}_{3}\right)_{2}\right]^{2+}$ & 110.1 & 194.2 & 225.2 \\
$(\mathbf{8})\left[\mathrm{Pt}\left(\mathrm{H}_{2} \mathrm{O}\right)_{3}\left(\mathrm{CF}_{3} \mathrm{SO}_{3}\right)_{3}\right]^{+}$ & 215.5 & 221.8 & 241.1 \\
(9) $\left[\mathrm{Pt}\left(\mathrm{H}_{2} \mathrm{O}\right)_{2}\left(\mathrm{CF}_{3} \mathrm{SO}_{3}\right)_{4}\right]$ & 185.8 & 236.5 & 240.6 \\
$(\mathbf{1 0})\left[\mathrm{Pt}\left(\mathrm{H}_{2} \mathrm{O}\right)_{4}(\mathrm{OH})\left(\mathrm{CF}_{3} \mathrm{SO}_{3}\right)\right]^{2+}$ & 126.8 & 158.6 & 169.1 \\
$(\mathbf{1 1})\left[\mathrm{Pt}\left(\mathrm{H}_{2} \mathrm{O}\right)_{3}(\mathrm{OH})_{2}\left(\mathrm{CF}_{3} \mathrm{SO}_{3}\right)\right]^{+}$ & 125.1 & 174.1 & 187.9 \\
$(\mathbf{1 2})\left[\mathrm{Pt}\left(\mathrm{H}_{2} \mathrm{O}\right)_{2}(\mathrm{OH})_{3}\left(\mathrm{CF}_{3} \mathrm{SO}_{3}\right)\right]$ & -72.4 & -69.5 & -67.8 \\
$(\mathbf{1 3})\left[\mathrm{Pt}\left(\mathrm{H}_{2} \mathrm{O}\right)_{3}(\mathrm{OH})\left(\mathrm{CF}_{3} \mathrm{SO}_{3}\right)_{2}\right]^{+}$ & 114.3 & 183.3 & 201.7 \\
$(\mathbf{1 4})\left[\mathrm{Pt}\left(\mathrm{H}_{2} \mathrm{O}\right)_{2}(\mathrm{OH})_{2}\left(\mathrm{CF}_{3} \mathrm{SO}_{3}\right)_{2}\right]$ & 76.2 & 110.1 & 106.3 \\
$(\mathbf{1 5})\left[\mathrm{Pt}\left(\mathrm{H}_{2} \mathrm{O}\right)_{2}(\mathrm{OH})\left(\mathrm{CF}_{3} \mathrm{SO}_{3}\right)_{3}\right]$ & 165.3 & 189.6 & 227.2 \\
\hline
\end{tabular}

Pt(II) and Pt(IV) complexes to see more details of structural change by the dielectric constant. The $\mathrm{Pt} \cdots \mathrm{O}$ distance with three ligands $\left(\mathrm{H}_{2} \mathrm{O}, \mathrm{OH}^{-}\right.$, and $\left.\mathrm{CF}_{3} \mathrm{SO}_{3}{ }^{-}\right)$for $\mathrm{Pt}(\mathrm{II})$ and $\mathrm{Pt}(\mathrm{IV})$ complexes are shown in Tables 6 and 7, respectively. The $\mathrm{Pt} \cdots \mathrm{O}$ distance of $\left[\mathrm{Pt}\left(\mathrm{H}_{2} \mathrm{O}\right)_{2}\right]^{2+}$ and $\left[\mathrm{Pt}\left(\mathrm{H}_{2} \mathrm{O}\right)_{6}\right]^{4+}$ is almost the same regardless of dielectric constant. By the substitution of $\mathrm{OH}^{-}$or $\mathrm{CF}_{3} \mathrm{SO}_{3}{ }^{-}$for $\mathrm{H}_{2} \mathrm{O}$, the $\mathrm{Pt} \cdots \mathrm{O}$ distance with $\mathrm{OH}^{-}$and $\mathrm{CF}_{3} \mathrm{SO}_{3}{ }^{-}$becomes longer when the dielectric constant becomes larger. Contrary, the $\mathrm{Pt} \cdots \mathrm{O}$ distance with $\mathrm{H}_{2} \mathrm{O}$ becomes shorter. This result indicates that the surrounding environment in electrolyte solution strongly influences the anionic species, $\mathrm{OH}^{-}$and $\mathrm{CF}_{3} \mathrm{SO}_{3}{ }^{-}$. These geometrical changes are one of the reasons for changing the stability and reactivity of $\mathrm{Pt}$ complexes. 


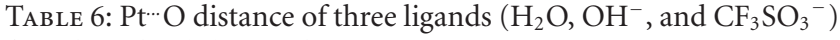
for selected $\mathrm{Pt}(\mathrm{II})$ complexes.

\begin{tabular}{lcccc}
\hline & Ligand & 5.0 & 20.0 & 61.0 \\
\hline (1) $\left[\mathrm{Pt}\left(\mathrm{H}_{2} \mathrm{O}\right)_{4}\right]^{2+}$ & $\mathrm{H}_{2} \mathrm{O}$ & 2.090 & 2.091 & 2.091 \\
(2) $\left[\mathrm{Pt}\left(\mathrm{H}_{2} \mathrm{O}\right)_{3}(\mathrm{OH})\right]^{+}$ & $\mathrm{H}_{2} \mathrm{O}$ & 2.143 & 2.132 & 2.131 \\
(5) $\left[\mathrm{Pt}(\mathrm{OH})_{4}\right]^{2-}$ & $\mathrm{OH}^{-}$ & 2.003 & 2.010 & 2.012 \\
(6) $\left[\mathrm{Pt}\left(\mathrm{H}_{2} \mathrm{O}\right)_{3}\left(\mathrm{CF}_{3} \mathrm{SO}_{3}\right)\right]^{+}$ & $\mathrm{OH}^{-}$ & 2.103 & 2.100 & 2.100 \\
& $\mathrm{H}_{2} \mathrm{O}$ & 2.108 & 2.103 & 2.101 \\
& $\mathrm{CF}_{3} \mathrm{SO}_{3}{ }^{-}$ & 2.066 & 2.070 & 2.077 \\
(8) $\left[\mathrm{Pt}\left(\mathrm{H}_{2} \mathrm{O}\right)_{2}(\mathrm{OH})\left(\mathrm{CF}_{3} \mathrm{SO}_{3}\right)\right]$ & $\mathrm{H}_{2} \mathrm{O}^{-}$ & 2.110 & 2.106 & 2.106 \\
& $\mathrm{OH}^{-}$ & 2.020 & 2.016 & 2.016 \\
& $\mathrm{CF}_{3} \mathrm{SO}_{3}{ }^{-}$ & 2.169 & 2.175 & 2.175 \\
\hline
\end{tabular}

TABle 7: Pt”O distance of three ligands $\left(\mathrm{H}_{2} \mathrm{O}, \mathrm{OH}^{-}\right.$, and $\left.\mathrm{CF}_{3} \mathrm{SO}_{3}{ }^{-}\right)$ for selected $\mathrm{Pt}(\mathrm{IV})$ complexes.

\begin{tabular}{lcccc}
\hline & Ligand & 5.0 & 20.0 & 61.0 \\
\hline (1) $\left[\mathrm{Pt}\left(\mathrm{H}_{2} \mathrm{O}\right)_{6}\right]^{4+}$ & $\mathrm{H}_{2} \mathrm{O}$ & 2.064 & 2.064 & 2.064 \\
(2) $\left[\mathrm{Pt}\left(\mathrm{H}_{2} \mathrm{O}\right)_{5}(\mathrm{OH})\right]^{3+}$ & $\mathrm{H}_{2} \mathrm{O}$ & 2.092 & 2.090 & 2.088 \\
& $\mathrm{OH}^{-}$ & 1.990 & 1.992 & 1.994 \\
(5) $\left[\mathrm{Pt}\left(\mathrm{H}_{2} \mathrm{O}\right)_{2}(\mathrm{OH})_{4}\right]$ & $\mathrm{H}_{2} \mathrm{O}$ & 2.218 & 2.208 & 2.202 \\
& $\mathrm{OH}^{-}$ & 2.035 & 2.038 & 2.040 \\
(6) $\left[\mathrm{Pt}\left(\mathrm{H}_{2} \mathrm{O}\right)_{5}\left(\mathrm{CF}_{3} \mathrm{SO}_{3}\right)\right]^{3+}$ & $\mathrm{H}_{2} \mathrm{O}$ & 2.093 & 2.088 & 2.085 \\
& $\mathrm{CF}_{3} \mathrm{SO}_{3}{ }^{-}$ & 2.038 & 2.039 & 2.042 \\
& $\mathrm{H}_{2} \mathrm{O}^{-}$ & 2.195 & 2.191 & 2.190 \\
(12) $\left[\mathrm{Pt}\left(\mathrm{H}_{2} \mathrm{O}\right)_{2}(\mathrm{OH})_{3}\left(\mathrm{CF}_{3} \mathrm{SO}_{3}\right)\right]$ & $\mathrm{OH}^{-}$ & 2.006 & 2.007 & 2.007 \\
& $\mathrm{CF}_{3} \mathrm{SO}_{3}{ }^{-}$ & 2.190 & 2.193 & 2.195 \\
\hline
\end{tabular}

3.4. Reactivity of Pt Complex. We discuss the reactivity of Pt complex, which is dissolved species from Pt surface, in PFSA environment. We focused on the reactivity based on the thermodynamical properties. The four reactions of Pt complexes are considered as shown by the following equations, taking $\left[\mathrm{Pt}\left(\mathrm{H}_{2} \mathrm{O}\right)_{3}(\mathrm{OH})\right]^{+}$as an example.

Proton addition reaction

$$
\left[\mathrm{Pt}\left(\mathrm{H}_{2} \mathrm{O}\right)_{3}(\mathrm{OH})\right]^{+}+\mathrm{H}_{3} \mathrm{O}^{+} \longrightarrow\left[\mathrm{Pt}\left(\mathrm{H}_{2} \mathrm{O}\right)_{4}\right]^{2+}+\mathrm{H}_{2} \mathrm{O}
$$

$\mathrm{H}_{2} \mathrm{O} / \mathrm{CF}_{3} \mathrm{SO}_{3}{ }^{-}$substitution reaction

$$
\begin{aligned}
{\left[\mathrm{Pt}\left(\mathrm{H}_{2} \mathrm{O}\right)_{3}(\mathrm{OH})\right]^{+}+\mathrm{CF}_{3} \mathrm{SO}_{3}{ }^{-} \longrightarrow } & {\left[\mathrm{Pt}\left(\mathrm{H}_{2} \mathrm{O}\right)_{2}(\mathrm{OH})\right.} \\
& \left.\left(\mathrm{CF}_{3} \mathrm{SO}_{3}\right)\right]+\mathrm{H}_{2} \mathrm{O}
\end{aligned}
$$

$\mathrm{OH}^{-} / \mathrm{CF}_{3} \mathrm{SO}_{3}{ }^{-}$substitution reaction

$$
\begin{aligned}
{\left[\mathrm{Pt}\left(\mathrm{H}_{2} \mathrm{O}\right)_{3}(\mathrm{OH})\right]^{+}+\mathrm{CF}_{3} \mathrm{SO}_{3}{ }^{-} \longrightarrow } & {\left[\mathrm{Pt}\left(\mathrm{H}_{2} \mathrm{O}\right)_{3}\left(\mathrm{CF}_{3} \mathrm{SO}_{3}\right)\right]^{+} } \\
& +\mathrm{OH}^{-}
\end{aligned}
$$

Reduction reaction from $\mathrm{Pt}(\mathrm{IV})$ to $\mathrm{Pt}(\mathrm{II})$ complex

$$
\left[\mathrm{Pt}\left(\mathrm{H}_{2} \mathrm{O}\right)_{5}(\mathrm{OH})\right]^{3+}+2 \mathrm{e}^{-} \longleftrightarrow\left[\mathrm{Pt}\left(\mathrm{H}_{2} \mathrm{O}\right)_{3}(\mathrm{OH})\right]^{+}+2 \mathrm{H}_{2} \mathrm{O}
$$

The reaction energies for (5), (6), and (7) of $\mathrm{Pt}(\mathrm{II})$ and $\mathrm{Pt}(\mathrm{IV})$ complexes are listed in Tables 8 and 9 , respectively.
For $\mathrm{Pt}(\mathrm{II})$ complexes, many proton addition reactions are thermodynamically favorable. It is noticed that the proton addition reaction energy to $\left[\mathrm{Pt}\left(\mathrm{H}_{2} \mathrm{O}\right)_{3}(\mathrm{OH})\right]^{+}$was only positive when $\varepsilon=5.0$. This result indicates that the $\left[\mathrm{Pt}\left(\mathrm{H}_{2} \mathrm{O}\right)_{4}\right]^{2+}$ is not formed in the low-humidity PFSA environment. The $\mathrm{H}_{2} \mathrm{O} / \mathrm{CF}_{3} \mathrm{SO}_{3}{ }^{-}$substitution reaction also becomes thermodynamically favorable with decreasing the dielectric property of the environment. On the other hand, the $\mathrm{OH}^{-} / \mathrm{CF}_{3} \mathrm{SO}_{3}{ }^{-}$substitution reaction is difficult.

For $\mathrm{Pt}(\mathrm{IV})$ complexes, the proton addition reaction to $\left[\mathrm{Pt}(\mathrm{OH})_{2}(\mathrm{OH})_{4}\right]$ becomes thermodynamically favorable with decreasing the dielectric constant. While the $\left[\mathrm{Pt}\left(\mathrm{H}_{2} \mathrm{O}\right)_{3}\right.$ $\left.(\mathrm{OH})_{3}\right]^{+}$will be possible complex by the proton addition reaction in water $(\varepsilon=61.0)$, the $\left[\mathrm{Pt}\left(\mathrm{H}_{2} \mathrm{O}_{4}(\mathrm{OH})_{2}\right)\right]^{2+}$ is not formed in PFSA environment $(\varepsilon=5.0$ and 20.0) by the positive proton addition reaction energy of $\left[\mathrm{Pt}\left(\mathrm{H}_{2} \mathrm{O}\right)_{3}(\mathrm{OH})_{3}\right]^{+}$. The product of proton addition reaction is different depending on the surrounding environment. We also found some negative proton addition reaction energy of $\mathrm{Pt}(\mathrm{IV})$ complexes including $\mathrm{CF}_{3} \mathrm{SO}_{3}{ }^{-}$, that is, $\left[\mathrm{Pt}\left(\mathrm{H}_{2} \mathrm{O}\right)_{3}\left(\mathrm{CF}_{3} \mathrm{SO}_{3}\right)_{3}\right]^{+}$ and $\left[\mathrm{Pt}\left(\mathrm{H}_{2} \mathrm{O}\right)_{3}(\mathrm{OH})\left(\mathrm{CF}_{3} \mathrm{SO}_{3}\right)_{2}\right]^{+}$. The $\mathrm{H}_{2} \mathrm{O} / \mathrm{CF}_{3} \mathrm{SO}_{3}{ }^{-}$and $\mathrm{OH}^{-} / \mathrm{CF}_{3} \mathrm{SO}_{3}{ }^{-}$substitution reactions for $\mathrm{Pt}(\mathrm{IV})$ complexes show a tendency (negative and positive reaction energies) similar to that of $\mathrm{Pt}(\mathrm{II})$ complexes.

The result of reduction reaction (8) from $\mathrm{Pt}(\mathrm{IV})$ to $\mathrm{Pt}$ (II) complexes is listed in Table 10. The reduction energies of $\left[\mathrm{Pt}\left(\mathrm{H}_{2} \mathrm{O}\right)_{6}\right]^{4+},\left[\mathrm{Pt}\left(\mathrm{H}_{2} \mathrm{O}\right)_{5}(\mathrm{OH})\right]^{3+}$, and $\left[\mathrm{Pt}\left(\mathrm{H}_{2} \mathrm{O}\right)_{4}\right.$ $\left.(\mathrm{OH})_{2}\right]^{2+}$ become smaller when the dielectric constant becomes larger. On the contrary, the reduction energy of $\left[\mathrm{Pt}\left(\mathrm{H}_{2} \mathrm{O}\right)_{2}(\mathrm{OH})_{4}\right]$ becomes larger. The reduction energy of $\left[\mathrm{Pt}\left(\mathrm{H}_{2} \mathrm{O}\right)_{3}(\mathrm{OH})_{3}\right]^{+}$was less influenced by the dielectric constant. These species, $\left[\mathrm{Pt}\left(\mathrm{H}_{2} \mathrm{O}\right)_{2}(\mathrm{OH})_{4}\right],\left[\mathrm{Pt}\left(\mathrm{H}_{2} \mathrm{O}\right)_{3}(\mathrm{OH})_{3}\right]^{+}$, and $\left[\mathrm{Pt}\left(\mathrm{H}_{2} \mathrm{O}\right)_{4}(\mathrm{OH})_{2}\right]^{2+}$, which are stabilized by proton addition reaction after desorption from $\mathrm{Pt}$ surface, would be important concerning the reduction reaction from $\mathrm{Pt}(\mathrm{IV})$ to $\mathrm{Pt}(\mathrm{II})$. Especially, the reduction from $\left[\mathrm{Pt}\left(\mathrm{H}_{2} \mathrm{O}\right)_{2}(\mathrm{OH})_{4}\right]$ or $\left[\mathrm{Pt}\left(\mathrm{H}_{2} \mathrm{O}\right)_{3}(\mathrm{OH})_{3}\right]^{+}$is favorable reaction during the $\mathrm{PEFC}$ operating condition. After reduction reaction from $\left[\mathrm{Pt}\left(\mathrm{H}_{2} \mathrm{O}\right)_{2}(\mathrm{OH})_{4}\right]$ or $\left[\mathrm{Pt}\left(\mathrm{H}_{2} \mathrm{O}\right)_{3}(\mathrm{OH})_{3}\right]^{+}$, the proton addition reaction for $\left[\mathrm{Pt}(\mathrm{OH})_{4}\right]^{2-}$ or $\left[\mathrm{Pt}\left(\mathrm{H}_{2} \mathrm{O}\right)(\mathrm{OH})_{3}\right]^{-}$proceeds proton addition reaction because the reaction energy of proton addition is more stable than the $\Delta E_{\text {des }}$. Then, the $\left[\mathrm{Pt}\left(\mathrm{H}_{2} \mathrm{O}\right)_{4}\right]^{2+}$, which is not stable under low-humidity condition, and $\left[\mathrm{Pt}\left(\mathrm{H}_{2} \mathrm{O}\right)_{3}(\mathrm{OH})\right]^{+}$are one of the reprecipitation species because of large positive $\Delta E_{\text {des }}$ between $\mathrm{Pt}(\mathrm{II})$ complex and Pt surface.

\section{Conclusions}

In this study, we calculated the $\Delta E_{f}$ and $\Delta G_{\text {solv }}$ of fourand six-coordinate $\mathrm{Pt}(\mathrm{II})$ and $\mathrm{Pt}(\mathrm{IV})$ complexes with three types of ligands $\left(\mathrm{H}_{2} \mathrm{O}, \mathrm{OH}^{-}\right.$, and $\left.\mathrm{CF}_{3} \mathrm{SO}_{3}{ }^{-}\right)$. To represent the low- and high-humidity condition in PFSA environment, we changed the dielectric constant and analyzed the stability and reactivity of $\mathrm{Pt}$ complexes. The stability of $\mathrm{Pt}$ complexes is changed by dielectric constant because the $\Delta E_{f}$ and $\Delta G_{\text {solv }}$, respectively, become larger and smaller when the dielectric constant becomes large. We also analyzed the $\Delta E_{\text {des }}$ of Pt complex from Pt surface. 
Table 8: Reaction energy ( $\Delta E)$ for Pt(II) complexes with various dielectric constants. Unit is kJ/mol.

\begin{tabular}{|c|c|c|c|}
\hline & 5.0 & 20.0 & 61.0 \\
\hline \multicolumn{4}{|l|}{ Proton addition reaction } \\
\hline (2) $\left[\mathrm{Pt}\left(\mathrm{H}_{2} \mathrm{O}\right)_{3}(\mathrm{OH})\right]^{+}+\mathrm{H}_{3} \mathrm{O}^{+} \rightarrow(\mathbf{1})\left[\mathrm{Pt}\left(\mathrm{H}_{2} \mathrm{O}\right)_{4}\right]^{2+}+\mathrm{H}_{2} \mathrm{O}$ & 29.3 & -21.8 & -29.3 \\
\hline (3) $\left[\mathrm{Pt}\left(\mathrm{H}_{2} \mathrm{O}\right)_{2}(\mathrm{OH})_{2}\right]+\mathrm{H}_{3} \mathrm{O}^{+} \rightarrow\left(\right.$ (2) $\left[\mathrm{Pt}\left(\mathrm{H}_{2} \mathrm{O}\right)_{3}(\mathrm{OH})\right]^{+}+\mathrm{H}_{2} \mathrm{O}$ & -123.0 & -92.9 & -90.4 \\
\hline (4) $\left[\mathrm{Pt}\left(\mathrm{H}_{2} \mathrm{O}\right)(\mathrm{OH})_{3}\right]^{-}+\mathrm{H}_{3} \mathrm{O}^{+} \rightarrow(3)\left[\mathrm{Pt}\left(\mathrm{H}_{2} \mathrm{O}\right)_{2}(\mathrm{OH})_{2}\right]+\mathrm{H}_{2} \mathrm{O}$ & -296.3 & -179.5 & -147.3 \\
\hline (5) $\left[\mathrm{Pt}(\mathrm{OH})_{4}\right]^{2-}+\mathrm{H}_{3} \mathrm{O}^{+} \rightarrow(4)\left[\mathrm{Pt}\left(\mathrm{H}_{2} \mathrm{O}\right)(\mathrm{OH})_{3}\right]^{-}+\mathrm{H}_{2} \mathrm{O}$ & -426.5 & -221.4 & -181.2 \\
\hline (8) $\left[\mathrm{Pt}\left(\mathrm{H}_{2} \mathrm{O}\right)_{2}(\mathrm{OH})\left(\mathrm{CF}_{3} \mathrm{SO}_{3}\right)\right]+\mathrm{H}_{3} \mathrm{O}^{+} \rightarrow(6)\left[\mathrm{Pt}\left(\mathrm{H}_{2} \mathrm{O}\right)_{3}\left(\mathrm{CF}_{3} \mathrm{SO}_{3}\right)\right]^{+}+\mathrm{H}_{2} \mathrm{O}$ & -82.4 & -50.2 & -59.4 \\
\hline \multicolumn{4}{|l|}{$\mathrm{H}_{2} \mathrm{O} / \mathrm{CF}_{3} \mathrm{SO}_{3}^{-}$substitution reaction } \\
\hline (1) $\left[\mathrm{Pt}\left(\mathrm{H}_{2} \mathrm{O}\right)_{4}\right]^{2+}+\mathrm{CF}_{3} \mathrm{SO}_{3}^{-} \rightarrow(\mathbf{6})\left[\mathrm{Pt}\left(\mathrm{H}_{2} \mathrm{O}\right)_{3}\left(\mathrm{CF}_{3} \mathrm{SO}_{3}\right)\right]^{+}+\mathrm{H}_{2} \mathrm{O}$ & -209.3 & -59.0 & -33.1 \\
\hline (6) $\left[\mathrm{Pt}\left(\mathrm{H}_{2} \mathrm{O}\right)_{3}\left(\mathrm{CF}_{3} \mathrm{SO}_{3}\right)\right]^{+}+\mathrm{CF}_{3} \mathrm{SO}_{3}^{-} \rightarrow(7)\left[\mathrm{Pt}\left(\mathrm{H}_{2} \mathrm{O}\right)_{2}\left(\mathrm{CF}_{3} \mathrm{SO}_{3}\right)_{2}\right]+\mathrm{H}_{2} \mathrm{O}$ & -119.7 & -33.9 & -5.9 \\
\hline (2) $\left[\mathrm{Pt}\left(\mathrm{H}_{2} \mathrm{O}\right)_{3}(\mathrm{OH})\right]^{+}+\mathrm{CF}_{3} \mathrm{SO}_{3}^{-} \rightarrow(\mathbf{8})\left[\mathrm{Pt}\left(\mathrm{H}_{2} \mathrm{O}\right)_{2}(\mathrm{OH})\left(\mathrm{CF}_{3} \mathrm{SO}_{3}\right)\right]+\mathrm{H}_{2} \mathrm{O}$ & -97.5 & -30.6 & -2.9 \\
\hline \multicolumn{4}{|l|}{$\mathrm{OH}^{-} / \mathrm{CF}_{3} \mathrm{SO}_{3}^{-}$substitution reaction } \\
\hline (2) $\left[\mathrm{Pt}\left(\mathrm{H}_{2} \mathrm{O}\right)_{3}(\mathrm{OH})\right]^{+}+\mathrm{CF}_{3} \mathrm{SO}_{3}^{-} \rightarrow(6)\left[\mathrm{Pt}\left(\mathrm{H}_{2} \mathrm{O}\right)_{3}\left(\mathrm{CF}_{3} \mathrm{SO}_{3}\right)\right]^{+}+\mathrm{OH}^{-}$ & 324.3 & 277.0 & 259.9 \\
\hline (3) $\left[\mathrm{Pt}\left(\mathrm{H}_{2} \mathrm{O}\right)_{2}(\mathrm{OH})_{2}\right]+\mathrm{CF}_{3} \mathrm{SO}_{3}^{-} \rightarrow(8)\left[\mathrm{Pt}\left(\mathrm{H}_{2} \mathrm{O}\right)_{2}(\mathrm{OH})\left(\mathrm{CF}_{3} \mathrm{SO}_{3}\right)\right]+\mathrm{OH}^{-}$ & 284.2 & 234.8 & 228.9 \\
\hline (8) $\left[\mathrm{Pt}\left(\mathrm{H}_{2} \mathrm{O}\right)_{2}(\mathrm{OH})\left(\mathrm{CF}_{3} \mathrm{SO}_{3}\right)\right]+\mathrm{CF}_{3} \mathrm{SO}_{3}^{-} \rightarrow(7)\left[\mathrm{Pt}\left(\mathrm{H}_{2} \mathrm{O}\right)_{2}\left(\mathrm{CF}_{3} \mathrm{SO}_{3}\right)_{2}\right]+\mathrm{OH}^{-}$ & 302.2 & 274.1 & 269.1 \\
\hline
\end{tabular}

TABLE 9: Reaction energy for Pt(IV) complexes with various dielectric constants. Unit is $\mathrm{kJ} / \mathrm{mol}$.

\begin{tabular}{|c|c|c|c|}
\hline & 5.0 & 20.0 & 61.0 \\
\hline \multicolumn{4}{|l|}{ Proton addition reaction } \\
\hline (2) $\left[\mathrm{Pt}\left(\mathrm{H}_{2} \mathrm{O}\right)_{5}(\mathrm{OH})\right]^{3+}+\mathrm{H}_{3} \mathrm{O}^{+} \rightarrow(\mathbf{1})\left[\mathrm{Pt}\left(\mathrm{H}_{2} \mathrm{O}\right)_{6}\right]^{4+}+\mathrm{H}_{2} \mathrm{O}$ & 396.3 & 182.5 & 141.5 \\
\hline (3) $\left[\mathrm{Pt}\left(\mathrm{H}_{2} \mathrm{O}\right)_{4}(\mathrm{OH})_{2}\right]^{2+}+\mathrm{H}_{3} \mathrm{O}^{+} \rightarrow(2)\left[\mathrm{Pt}\left(\mathrm{H}_{2} \mathrm{O}\right)_{5}(\mathrm{OH})\right]^{3+}+\mathrm{H}_{2} \mathrm{O}$ & 216.4 & 105.5 & 63.6 \\
\hline (4) $\left[\mathrm{Pt}\left(\mathrm{H}_{2} \mathrm{O}\right)_{3}(\mathrm{OH})_{3}\right]^{+}+\mathrm{H}_{3} \mathrm{O}^{+} \rightarrow(3)\left[\mathrm{Pt}\left(\mathrm{H}_{2} \mathrm{O}\right)_{4}(\mathrm{OH})_{2}\right]^{2+}+\mathrm{H}_{2} \mathrm{O}$ & 63.6 & 18.0 & -1.3 \\
\hline (5) $\left[\mathrm{Pt}\left(\mathrm{H}_{2} \mathrm{O}\right)_{2}(\mathrm{OH})_{4}\right]+\mathrm{H}_{3} \mathrm{O}^{+} \rightarrow(\mathbf{4})\left[\mathrm{Pt}\left(\mathrm{H}_{2} \mathrm{O}\right)_{3}(\mathrm{OH})_{3}\right]^{+}+\mathrm{H}_{2} \mathrm{O}$ & -120.5 & -89.1 & -74.1 \\
\hline (10) $\left[\mathrm{Pt}\left(\mathrm{H}_{2} \mathrm{O}\right)_{4}(\mathrm{OH})\left(\mathrm{CF}_{3} \mathrm{SO}_{3}\right)\right]^{2+}+\mathrm{H}_{3} \mathrm{O}^{+} \rightarrow(\mathbf{6})\left[\mathrm{Pt}\left(\mathrm{H}_{2} \mathrm{O}\right)_{5}\left(\mathrm{CF}_{3} \mathrm{SO}_{3}\right)\right]^{3+}+\mathrm{H}_{2} \mathrm{O}$ & 222.2 & 137.7 & 94.6 \\
\hline (11) $\left[\mathrm{Pt}\left(\mathrm{H}_{2} \mathrm{O}\right)_{3}(\mathrm{OH})_{2}\left(\mathrm{CF}_{3} \mathrm{SO}_{3}\right)\right]^{+}+\mathrm{H}_{3} \mathrm{O}^{+} \rightarrow(\mathbf{1 0})\left[\mathrm{Pt}\left(\mathrm{H}_{2} \mathrm{O}\right)_{4}(\mathrm{OH})\left(\mathrm{CF}_{3} \mathrm{SO}_{3}\right)\right]^{2+}+\mathrm{H}_{2} \mathrm{O}$ & 57.3 & 8.0 & 0.0 \\
\hline (12) $\left[\mathrm{Pt}\left(\mathrm{H}_{2} \mathrm{O}\right)_{2}(\mathrm{OH})_{3}\left(\mathrm{CF}_{3} \mathrm{SO}_{3}\right)\right]+\mathrm{H}_{3} \mathrm{O}^{+} \rightarrow(11)\left[\mathrm{Pt}\left(\mathrm{H}_{2} \mathrm{O}\right)_{3}(\mathrm{OH})_{2}\left(\mathrm{CF}_{3} \mathrm{SO}_{3}\right)\right]^{+}+\mathrm{H}_{2} \mathrm{O}$ & 7.1 & 28.0 & 35.6 \\
\hline (13) $\left[\mathrm{Pt}\left(\mathrm{H}_{2} \mathrm{O}\right)_{3}(\mathrm{OH})\left(\mathrm{CF}_{3} \mathrm{SO}_{3}\right)_{2}\right]^{+}+\mathrm{H}_{3} \mathrm{O}^{+} \rightarrow(7)\left[\mathrm{Pt}\left(\mathrm{H}_{2} \mathrm{O}\right)_{4}\left(\mathrm{CF}_{3} \mathrm{SO}_{3}\right)_{2}\right]^{2+}+\mathrm{H}_{2} \mathrm{O}$ & 117.2 & 85.8 & 58.2 \\
\hline (14) $\left[\mathrm{Pt}\left(\mathrm{H}_{2} \mathrm{O}\right)_{2}(\mathrm{OH})_{2}\left(\mathrm{CF}_{3} \mathrm{SO}_{3}\right)_{2}\right]+\mathrm{H}_{3} \mathrm{O}^{+} \rightarrow(\mathbf{1 3})\left[\mathrm{Pt}\left(\mathrm{H}_{2} \mathrm{O}\right)_{3}(\mathrm{OH})\left(\mathrm{CF}_{3} \mathrm{SO}_{3}\right)_{2}\right]^{+}+\mathrm{H}_{2} \mathrm{O}$ & -9.2 & -0.4 & 13.8 \\
\hline (15) $\left[\mathrm{Pt}\left(\mathrm{H}_{2} \mathrm{O}\right)_{2}(\mathrm{OH})\left(\mathrm{CF}_{3} \mathrm{SO}_{3}\right)_{3}\right]+\mathrm{H}_{3} \mathrm{O}^{+} \rightarrow(8)\left[\mathrm{Pt}\left(\mathrm{H}_{2} \mathrm{O}\right)_{3}\left(\mathrm{CF}_{3} \mathrm{SO}_{3}\right)_{3}\right]^{+}+\mathrm{H}_{2} \mathrm{O}$ & -3.3 & -53.1 & -13.0 \\
\hline \multicolumn{4}{|l|}{$\mathrm{H}_{2} \mathrm{O} / \mathrm{CF}_{3} \mathrm{SO}_{3}^{-}$substitution reaction } \\
\hline (1) $\left[\mathrm{Pt}\left(\mathrm{H}_{2} \mathrm{O}\right)_{6}\right]^{4+}+\mathrm{CF}_{3} \mathrm{SO}_{3}^{-} \rightarrow(6)\left[\mathrm{Pt}\left(\mathrm{H}_{2} \mathrm{O}\right)_{5}\left(\mathrm{CF}_{3} \mathrm{SO}_{3}\right)\right]^{3+}+\mathrm{H}_{2} \mathrm{O}$ & -502.6 & -158.6 & -87.5 \\
\hline (6) $\left[\mathrm{Pt}\left(\mathrm{H}_{2} \mathrm{O}\right)_{5}\left(\mathrm{CF}_{3} \mathrm{SO}_{3}\right)\right]^{3+}+\mathrm{CF}_{3} \mathrm{SO}_{3}^{-} \rightarrow(7)\left[\mathrm{Pt}\left(\mathrm{H}_{2} \mathrm{O}\right)_{4}\left(\mathrm{CF}_{3} \mathrm{SO}_{3}\right)_{2}\right]^{2+}+\mathrm{H}_{2} \mathrm{O}$ & -349.0 & -135.6 & -74.9 \\
\hline (7) $\left[\mathrm{Pt}\left(\mathrm{H}_{2} \mathrm{O}\right)_{4}\left(\mathrm{CF}_{3} \mathrm{SO}_{3}\right)_{2}\right]^{2+}+\mathrm{CF}_{3} \mathrm{SO}_{3}^{-} \rightarrow(8)\left[\mathrm{Pt}\left(\mathrm{H}_{2} \mathrm{O}\right)_{3}\left(\mathrm{CF}_{3} \mathrm{SO}_{3}\right)_{3}\right]^{+}+\mathrm{H}_{2} \mathrm{O}$ & -258.2 & -90.8 & -56.5 \\
\hline (8) $\left[\mathrm{Pt}\left(\mathrm{H}_{2} \mathrm{O}\right)_{3}\left(\mathrm{CF}_{3} \mathrm{SO}_{3}\right)_{3}\right]^{+}+\mathrm{CF}_{3} \mathrm{SO}_{3}^{-} \rightarrow\left(\right.$ 9) $\left[\mathrm{Pt}\left(\mathrm{H}_{2} \mathrm{O}\right)_{2}\left(\mathrm{CF}_{3} \mathrm{SO}_{3}\right)_{4}\right]+\mathrm{H}_{2} \mathrm{O}$ & -127.2 & -56.9 & -30.6 \\
\hline (2) $\left[\mathrm{Pt}\left(\mathrm{H}_{2} \mathrm{O}\right)_{5}(\mathrm{OH})\right]^{3+}+\mathrm{CF}_{3} \mathrm{SO}_{3}^{-} \rightarrow(10)\left[\mathrm{Pt}\left(\mathrm{H}_{2} \mathrm{O}\right)_{4}(\mathrm{OH})\left(\mathrm{CF}_{3} \mathrm{SO}_{3}\right)\right]^{2+}+\mathrm{H}_{2} \mathrm{O}$ & -328.9 & -113.8 & -40.6 \\
\hline (10) $\left[\mathrm{Pt}\left(\mathrm{H}_{2} \mathrm{O}\right)_{4}(\mathrm{OH})\left(\mathrm{CF}_{3} \mathrm{SO}_{3}\right)\right]^{2+}+\mathrm{CF}_{3} \mathrm{SO}_{3}^{-} \rightarrow\left(\right.$ 13) $\left[\mathrm{Pt}\left(\mathrm{H}_{2} \mathrm{O}\right)_{3}(\mathrm{OH})\left(\mathrm{CF}_{3} \mathrm{SO}_{3}\right)_{2}\right]^{+}+\mathrm{H}_{2} \mathrm{O}$ & -244.0 & -84.1 & -38.5 \\
\hline (13) $\left[\mathrm{Pt}\left(\mathrm{H}_{2} \mathrm{O}\right)_{3}(\mathrm{OH})\left(\mathrm{CF}_{3} \mathrm{SO}_{3}\right)_{2}\right]^{+}+\mathrm{CF}_{3} \mathrm{SO}_{3}^{-} \rightarrow\left(\right.$ (15) $\left[\mathrm{Pt}\left(\mathrm{H}_{2} \mathrm{O}\right)_{2}(\mathrm{OH})\left(\mathrm{CF}_{3} \mathrm{SO}_{3}\right)_{3}\right]+\mathrm{H}_{2} \mathrm{O}$ & -144.4 & -57.8 & -11.3 \\
\hline (3) $\left[\mathrm{Pt}\left(\mathrm{H}_{2} \mathrm{O}\right)_{4}(\mathrm{OH})_{2}\right]^{2+}+\mathrm{CF}_{3} \mathrm{SO}_{3}^{-} \rightarrow(11)\left[\mathrm{Pt}\left(\mathrm{H}_{2} \mathrm{O}\right)_{3}(\mathrm{OH})_{2}\left(\mathrm{CF}_{3} \mathrm{SO}_{3}\right)\right]^{+}+\mathrm{H}_{2} \mathrm{O}$ & -169.9 & -16.7 & -23.0 \\
\hline (11) $\left[\mathrm{Pt}\left(\mathrm{H}_{2} \mathrm{O}\right)_{3}(\mathrm{OH})_{2}\left(\mathrm{CF}_{3} \mathrm{SO}_{3}\right)\right]^{+}+\mathrm{CF}_{3} \mathrm{SO}_{3}^{-} \rightarrow\left(\right.$ 14) $\left[\mathrm{Pt}\left(\mathrm{H}_{2} \mathrm{O}\right)_{2}(\mathrm{OH})_{2}\left(\mathrm{CF}_{3} \mathrm{SO}_{3}\right)_{2}\right]+\mathrm{H}_{2} \mathrm{O}$ & -177.0 & -75.7 & -52.3 \\
\hline (4) $\left[\mathrm{Pt}\left(\mathrm{H}_{2} \mathrm{O}\right)_{3}(\mathrm{OH})_{3}\right]^{+}+\mathrm{CF}_{3} \mathrm{SO}_{3}^{-} \rightarrow(12)\left[\mathrm{Pt}\left(\mathrm{H}_{2} \mathrm{O}\right)_{2}(\mathrm{OH})_{3}\left(\mathrm{CF}_{3} \mathrm{SO}_{3}\right)\right]+\mathrm{H}_{2} \mathrm{O}$ & -113.4 & -26.4 & -14.2 \\
\hline \multicolumn{4}{|l|}{$\mathrm{OH}^{-} / \mathrm{CF}_{3} \mathrm{SO}_{3}^{-}$substitution reaction } \\
\hline (2) $\left[\mathrm{Pt}\left(\mathrm{H}_{2} \mathrm{O}\right)_{5}(\mathrm{OH})\right]^{3+}+\mathrm{CF}_{3} \mathrm{SO}_{3}^{-} \rightarrow(\mathbf{6})\left[\mathrm{Pt}\left(\mathrm{H}_{2} \mathrm{O}\right)_{5}\left(\mathrm{CF}_{3} \mathrm{SO}_{3}\right)\right]^{3+}+\mathrm{OH}^{-}$ & 398.0 & 381.7 & 376.2 \\
\hline (3) $\left[\mathrm{Pt}\left(\mathrm{H}_{2} \mathrm{O}\right)_{4}(\mathrm{OH})_{2}\right]^{2+}+\mathrm{CF}_{3} \mathrm{SO}_{3}{ }^{-} \rightarrow(\mathbf{1 0})\left[\mathrm{Pt}\left(\mathrm{H}_{2} \mathrm{O}\right)_{4}(\mathrm{OH})\left(\mathrm{CF}_{3} \mathrm{SO}_{3}\right)\right]^{2+}+\mathrm{OH}^{-}$ & 392.1 & 349.4 & 345.3 \\
\hline (4) $\left[\mathrm{Pt}\left(\mathrm{H}_{2} \mathrm{O}\right)_{3}(\mathrm{OH})_{3}\right]^{+}+\mathrm{CF}_{3} \mathrm{SO}_{3}^{-} \rightarrow(11)\left[\mathrm{Pt}\left(\mathrm{H}_{2} \mathrm{O}\right)_{3}(\mathrm{OH})_{2}\left(\mathrm{CF}_{3} \mathrm{SO}_{3}\right)\right]^{+}+\mathrm{OH}^{-}$ & 398.4 & 359.5 & 344.0 \\
\hline (5) $\left[\mathrm{Pt}\left(\mathrm{H}_{2} \mathrm{O}\right)_{2}(\mathrm{OH})_{4}\right]+\mathrm{CF}_{3} \mathrm{SO}_{3}^{-} \rightarrow(\mathbf{1 2})\left[\mathrm{Pt}\left(\mathrm{H}_{2} \mathrm{O}\right)_{2}(\mathrm{OH})_{3}\left(\mathrm{CF}_{3} \mathrm{SO}_{3}\right)\right]+\mathrm{OH}^{-}$ & 270.8 & 242.3 & 236.9 \\
\hline (10) $\left[\mathrm{Pt}\left(\mathrm{H}_{2} \mathrm{O}\right)_{4}(\mathrm{OH})\left(\mathrm{CF}_{3} \mathrm{SO}_{3}\right)\right]^{2+}+\mathrm{CF}_{3} \mathrm{SO}_{3}^{-} \rightarrow(7)\left[\mathrm{Pt}\left(\mathrm{H}_{2} \mathrm{O}\right)_{4}\left(\mathrm{CF}_{3} \mathrm{SO}_{3}\right)_{2}\right]^{2+}+\mathrm{OH}^{-}$ & 377.9 & 359.9 & 341.9 \\
\hline (11) $\left[\mathrm{Pt}\left(\mathrm{H}_{2} \mathrm{O}\right)_{3}(\mathrm{OH})_{2}\left(\mathrm{CF}_{3} \mathrm{SO}_{3}\right)\right]^{+}+\mathrm{CF}_{3} \mathrm{SO}_{3}^{-} \rightarrow(13)\left[\mathrm{Pt}\left(\mathrm{H}_{2} \mathrm{O}\right)_{3}(\mathrm{OH})\left(\mathrm{CF}_{3} \mathrm{SO}_{3}\right)_{2}\right]^{+}+\mathrm{OH}^{-}$ & 318.1 & 282.1 & 284.2 \\
\hline (12) $\left[\mathrm{Pt}\left(\mathrm{H}_{2} \mathrm{O}\right)_{2}(\mathrm{OH})_{3}\left(\mathrm{CF}_{3} \mathrm{SO}_{3}\right)\right]+\mathrm{CF}_{3} \mathrm{SO}_{3}^{-} \rightarrow\left(\right.$ 14) $\left[\mathrm{Pt}\left(\mathrm{H}_{2} \mathrm{O}\right)_{2}(\mathrm{OH})_{2}\left(\mathrm{CF}_{3} \mathrm{SO}_{3}\right)_{2}\right]+\mathrm{OH}^{-}$ & 334.4 & 310.5 & 305.9 \\
\hline (13) $\left[\mathrm{Pt}\left(\mathrm{H}_{2} \mathrm{O}\right)_{3}(\mathrm{OH})\left(\mathrm{CF}_{3} \mathrm{SO}_{3}\right)_{2}\right]^{+}+\mathrm{CF}_{3} \mathrm{SO}_{3}^{-} \rightarrow(8)\left[\mathrm{Pt}\left(\mathrm{H}_{2} \mathrm{O}\right)_{3}\left(\mathrm{CF}_{3} \mathrm{SO}_{3}\right)_{3}\right]^{+}$ & 363.7 & 353.2 & 323.9 \\
\hline (14) $\left[\mathrm{Pt}\left(\mathrm{H}_{2} \mathrm{O}\right)_{2}(\mathrm{OH})_{2}\left(\mathrm{CF}_{3} \mathrm{SO}_{3}\right)_{2}\right]+\mathrm{CF}_{3} \mathrm{SO}_{3}^{-} \rightarrow(15)\left[\mathrm{Pt}\left(\mathrm{H}_{2} \mathrm{O}\right)_{2}(\mathrm{OH})\left(\mathrm{CF}_{3} \mathrm{SO}_{3}\right)_{3}\right]+\mathrm{OH}^{-}$ & 351.1 & 300.1 & 324.8 \\
\hline (15) $\left[\mathrm{Pt}\left(\mathrm{H}_{2} \mathrm{O}\right)_{2}(\mathrm{OH})\left(\mathrm{CF}_{3} \mathrm{SO}_{3}\right)_{3}\right]+\mathrm{CF}_{3} \mathrm{SO}_{3}^{-} \rightarrow(9)\left[\mathrm{Pt}\left(\mathrm{H}_{2} \mathrm{O}\right)_{2}\left(\mathrm{CF}_{3} \mathrm{SO}_{3}\right)_{4}\right]+\mathrm{OH}^{-}$ & 380.8 & 354.1 & 304.7 \\
\hline
\end{tabular}


TAble 10: Reduction energy from Pt(IV) to Pt(II) complexes with various dielectric constants. Unit is V.

\begin{tabular}{|c|c|c|c|}
\hline $\mathrm{Pt}(\mathrm{IV})$ complex $\leftrightarrow \mathrm{pt}(\mathrm{II})$ complex & 5.0 & 20.0 & 61.0 \\
\hline (1) $\left[\mathrm{Pt}\left(\mathrm{H}_{2} \mathrm{O}\right)_{6}\right]^{4+}+2 \mathrm{e}^{-} \leftrightarrow(\mathbf{1})\left[\mathrm{Pt}\left(\mathrm{H}_{2} \mathrm{O}\right)_{4}\right]^{2+}+2 \mathrm{H}_{2} \mathrm{O}$ & 6.12 & 3.81 & 3.21 \\
\hline (2) $\left[\mathrm{Pt}\left(\mathrm{H}_{2} \mathrm{O}\right)_{5}(\mathrm{OH})\right]^{3+}+2 \mathrm{e}^{-} \leftrightarrow(2)\left[\mathrm{Pt}\left(\mathrm{H}_{2} \mathrm{O}\right)_{3}(\mathrm{OH})\right]^{+}+2 \mathrm{H}_{2} \mathrm{O}$ & 4.22 & 2.71 & 2.27 \\
\hline (3) $\left[\mathrm{Pt}\left(\mathrm{H}_{2} \mathrm{O}\right)_{4}(\mathrm{OH})_{2}\right]^{2+}+2 \mathrm{e}^{-} \leftrightarrow(3)\left[\mathrm{Pt}\left(\mathrm{H}_{2} \mathrm{O}\right)_{2}(\mathrm{OH})_{2}\right]+2 \mathrm{H}_{2} \mathrm{O}$ & 2.46 & 1.68 & 1.47 \\
\hline (4) $\left[\mathrm{Pt}\left(\mathrm{H}_{2} \mathrm{O}\right)_{3}(\mathrm{OH})_{3}\right]^{+}+2 \mathrm{e}^{-} \leftrightarrow(4)\left[\mathrm{Pt}\left(\mathrm{H}_{2} \mathrm{O}\right)(\mathrm{OH})_{3}\right]^{-}+2 \mathrm{H}_{2} \mathrm{O}$ & 0.60 & 0.66 & 0.71 \\
\hline (5) $\left[\mathrm{Pt}\left(\mathrm{H}_{2} \mathrm{O}\right)_{2}(\mathrm{OH})_{4}\right]+2 \mathrm{e}^{-} \leftrightarrow(5)\left[\mathrm{Pt}(\mathrm{OH})_{4}\right]^{2-}+2 \mathrm{H}_{2} \mathrm{O}$ & -0.99 & -0.13 & 0.14 \\
\hline
\end{tabular}

We found three important complexes, $\left[\mathrm{Pt}\left(\mathrm{H}_{2} \mathrm{O}\right)_{2}(\mathrm{OH})_{4}\right]$, $\left[\mathrm{Pt}\left(\mathrm{H}_{2} \mathrm{O}\right)_{2}(\mathrm{OH})_{3}\left(\mathrm{CF}_{3} \mathrm{SO}_{3}\right)\right]$, and $\left[\mathrm{Pt}(\mathrm{OH})_{4}\right]^{2-}$, for the initial $\mathrm{Pt}$ dissolution mechanism. The degradation of $\mathrm{Pt}$ complex from $\mathrm{Pt}$ surface is to be accelerated by the adsorption of $\mathrm{CF}_{3} \mathrm{SO}_{3}{ }^{-}$on the $\mathrm{Pt}$ surface because the $\Delta E_{\mathrm{des}}$ of $\left[\mathrm{Pt}\left(\mathrm{H}_{2} \mathrm{O}\right)_{2}(\mathrm{OH})_{3}\left(\mathrm{CF}_{3} \mathrm{SO}_{3}\right)\right]$ was smaller than that of $\left[\mathrm{Pt}\left(\mathrm{H}_{2} \mathrm{O}\right)_{2}(\mathrm{OH})_{4}\right]$. The possible pathways, proton addition, $\mathrm{H}_{2} \mathrm{O} / \mathrm{CF}_{3} \mathrm{SO}_{3}{ }^{-}, \mathrm{OH}^{-} / \mathrm{CF}_{3} \mathrm{SO}_{3}{ }^{-}$, and reduction reactions, are analyzed between the $\mathrm{Pt}$ complexes. The $\left[\mathrm{Pt}\left(\mathrm{H}_{2} \mathrm{O}\right)_{2}\right]^{2+}$ are not stabilized in PFSA environment under the low-humidity condition. The different stable species, $\left[\mathrm{Pt}\left(\mathrm{H}_{2} \mathrm{O}\right)_{3}(\mathrm{OH})_{3}\right]^{+}$ and $\left[\mathrm{Pt}\left(\mathrm{H}_{2} \mathrm{O}\right)_{4}(\mathrm{OH})^{2}\right]^{2+}$, are obtained by the proton addition reaction from $\left[\mathrm{Pt}\left(\mathrm{H}_{2} \mathrm{O}\right)_{2}(\mathrm{OH})_{4}\right]$ in PFSA and water environment, respectively. The $\left[\mathrm{Pt}\left(\mathrm{H}_{2} \mathrm{O}\right)_{4}\right]^{2+}$ and $\left[\mathrm{Pt}\left(\mathrm{H}_{2} \mathrm{O}\right)_{3}\right.$ $(\mathrm{OH})]^{+}$are possible reprecipitation species. This result suggests that the surrounding dielectric environment will change the reaction pathways of the dissolved $\mathrm{Pt}$ complexes. We theoretically estimated the effect of surrounding condition in PFSA environment for the Pt dissolution and reprecipitation mechanisms in comparison with water solution.

\section{Acknowledgment}

The authors are grateful for the financial support from KYOCERA corporation.

\section{References}

[1] Y. Shao-Horn, W. C. Sheng, S. Chen, P. J. Ferreira, E. F. Holby, and D. Morgan, "Instability of supported platinum nanoparticles in low-temperature fuel cells," Topics in Catalysis, vol. 46, no. 3-4, pp. 285-305, 2007.

[2] R. Borup, J. Meyers, B. Pivovar et al., "Scientific aspects of polymer electrolyte fuel cell durability and degradation," Chemical Reviews, vol. 107, no. 10, pp. 3904-3951, 2007.

[3] K. Yasuda, A. Taniguchi, T. Akita, T. Ioroi, and Z. Siroma, "Characteristics of a platinum black catalyst layer with regard to platinum dissolution phenomena in a membrane electrode assembly," Journal of the Electrochemical Society, vol. 153, no. 8, pp. A1599-A1603, 2006.

[4] J. Xie, D. L. Wood III, D. M. Wayne, T. A. Zawodzinski, P. Atanassov, and R. L. Borup, "Durability of PEFCs at high humidity conditions," Journal of the Electrochemical Society, vol. 152, no. 1, pp. A104-A113, 2005.

[5] E. Antolini, J. R. C. Salgado, R. M. da Silva, and E. R. Gonzalez, "Preparation of carbon supported binary Pt-M alloy catalysts ( $\mathrm{M}=$ first row transition metals) by low/medium temperature methods," Materials Chemistry and Physics, vol. 101, no. 2-3, pp. 395-403, 2007.
[6] S. Takizawa, A. Nakazawa, M. Inoue, and M. Umeda, "Anodic Pt dissolution in concentrated trifluoromethanesulfonic acid," Journal of Power Sources, vol. 195, no. 18, pp. 5966-5970, 2010.

[7] Project Annual Report for FYH20 (ID: 100014110), http:// www.nedo.go.jp/.

[8] M. Umeda, Y. Kuwahara, A. Nakazawa, and M. Inoue, "Pt degradation mechanism in concentrated sulfuric acid studied using rotating ring-disk electrode and electrochemical quartz crystal microbalance," Journal of Physical Chemistry C, vol. 113, no. 35, pp. 15707-15713, 2009.

[9] L. Kim, C. G. Chung, Y. W. Sung, and J. S. Chung, "Dissolution and migration of platinum after long-term operation of a polymer electrolyte fuel cell under various conditions," Journal of Power Sources, vol. 183, no. 2, pp. 524-532, 2008.

[10] S. Mitsushima, Y. Koizumi, S. Uzuka, and K. I. Ota, "Dissolution of platinum in acidic media," Electrochimica Acta, vol. 54, no. 2, pp. 455-460, 2008.

[11] X. Yu and S. Ye, "Recent advances in activity and durability enhancement of $\mathrm{Pt} / \mathrm{C}$ catalytic cathode in PEMFC. Part II: degradation mechanism and durability enhancement of carbon supported platinum catalyst," Journal of Power Sources, vol. 172, no. 1, pp. 145-154, 2007.

[12] W. Bi, G. E. Gray, and T. F. Fuller, "PEM fuel cell PtC dissolution and deposition in Nafion electrolyte," Electrochemical and Solid-State Letters, vol. 10, no. 5, pp. B101-B104, 2007.

[13] H. Yoshida, T. Kinumoto, Y. Iriyama, Y. Uchimoto, and Z. Ogumi, "XAS study for degradation mechanism of Pt/C catalyst during potential cycling test," ECS Transactions, vol. 11, no. 1, pp. 1321-1329, 2007.

[14] S. Mitsushima, S. Kawahara, K. Ota, and N. Kamiya, "Consumption rate of Pt under potential cycling," Journal of the Electrochemical Society, vol. 154, no. 2, pp. B153-B158, 2007.

[15] X. Wang, R. Kumar, and D. J. Myers, "Effect of voltage on platinum dissolution," Electrochemical and Solid-State Letters, vol. 9, no. 5, pp. A225-A227, 2006.

[16] T. Ishimoto, T. Ogura, M. Umeda, and M. Koyama, “Theoretical study on dissolution and reprecipitation mechanism of $\mathrm{Pt}$ complex in Pt electrocatalyst," Journal of Physical Chemistry C, vol. 115, no. 7, pp. 3136-3142, 2011.

[17] H. Schulenburg, B. Schwanitz, J. Krbanjevic, N. Linse, G. G. Scherer, and A. Wokaun, "Quantification of platinum deposition in polymer electrolyte fuel cell membranes," Electrochemistry Communications, vol. 13, no. 9, pp. 921-923, 2011.

[18] A. S. Danerol, C. Bas, L. Flandin, E. Claude, and N. D. Alberola, "Influence of ageing in fuel cell on membrane/ electrodes interfaces," Journal of Power Sources, vol. 196, no. 7, pp. 3479-3484, 2011.

[19] S. Mitsushima, K. Shinkoda, K. Matsuzawa, and K. Ota, "Solubility and permeability of Pt ion in polymer electrolyte," in Proceedings of the 62nd Annual Meeting of the International 
Society of Electrochemistry Abstract, Niigata, Japan, September 2011.

[20] A. M. Gómez-Marín, A. Berná, and J. M. Feliu, "Spectroelectrochemical studies of the $\mathrm{Pt}(111) /$ Nafion interface cast electrode," Journal of Physical Chemistry C, vol. 114, no. 47, pp. 20130-20140, 2010.

[21] R. Subbaraman, D. Strmcnik, V. Stamenkovic, and N. M. Markovic, "Three phase interfaces at electrified metal-solid electrolyte systems 1 . Study of the pt(hkl)-Nafion interface," Journal of Physical Chemistry C, vol. 114, no. 18, pp. 84148422, 2010.

[22] A. Ohma, K. Fushinobu, and K. Okazaki, "Influence of Nafion film on oxygen reduction reaction and hydrogen peroxide formation on Pt electrode for proton exchange membrane fuel cell," Electrochimica Acta, vol. 55, no. 28, pp. 8829-8838, 2010.

[23] O. J. Curnick, P. M. Mendes, and B. G. Pollet, "Enhanced durability of a Pt/C electrocatalyst derived from Nafionstabilised colloidal platinum nanoparticles," Electrochemistry Communications, vol. 12, no. 8, pp. 1017-1020, 2010.

[24] J. Healy, C. Hayden, T. Xie et al., "Aspects of the chemical degradation of PFSA ionomers used in PEM fuel cellsx," Fuel Cells, vol. 5, no. 2, pp. 302-308, 2005.

[25] S. D. Knights, K. M. Colbow, J. St-Pierre, and D. P. Wilkinson, "Aging mechanisms and lifetime of PEFC and DMFC," Journal of Power Sources, vol. 127, no. 1-2, pp. 127-134, 2004.

[26] E. Endoh, S. Terazono, W. Hardiyanto, and T. Yasuyuki, "Degradation study of MEA for PEMFCs under low humidity conditions," Electrochemical and Solid-State Letters, vol. 7, no. 7, pp. A209-A211, 2004.

[27] B. Delley, "From molecules to solids with the $\mathrm{DMol}^{3}$ approach," Journal of Chemical Physics, vol. 113, no. 18, pp. 7756-7764, 2000.

[28] B. Delley, "An all-electron numerical method for solving the local density functional for polyatomic molecules," The Journal of Chemical Physics, vol. 92, no. 1, pp. 508-517, 1990.

[29] S. J. Paddison, D. W. Reagor, and T. A. Zawodzinski Jr., "High frequency dielectric studies of hydrated Nafion," Journal of Electroanalytical Chemistry, vol. 459, no. 1, pp. 91-97, 1998.

[30] G. Oster and J. G. Kirkwood, "The influence of hindered molecular rotation on the dielectric constants of water, alcohols, and other polar liquids," The Journal of Chemical Physics, vol. 11, no. 4, pp. 175-178, 1943.

[31] F. Kodera, Y. Kuwahara, A. Nakazawa, and M. Umeda, "Electrochemical corrosion of platinum electrode in concentrated sulfuric acid," Journal of Power Sources, vol. 172, no. 2, pp. 698703, 2007.

[32] J. F. Llopis and F. Colom, Encyclopedia of Electrochemistry of The Elements, vol. 6, Edited by A. J. Bard, Marcel Decker, New York, NY, USA, 1976.

[33] K. Shimazu and H. Kita, "In situ measurements of water adsorption on a platinum electrode by an electrochemical quartz crystal microbalance," Journal of Electroanalytical Chemistry, vol. 341, no. 1-2, pp. 361-367, 1992.

[34] T. Ishimoto, T. Ogura, R. Nagumo, and M. Koyama, "Theoretical study on dissolved structure of Pt complex in polymer electrolyte fuel cell," ECS Transactions, vol. 25, no. 1, pp. 799806, 2009.

[35] A. Roudgar, M. Eikerling, and R. van Santen, "Ab initio study of oxygen reduction mechanism at $\mathrm{Pt}_{4}$ cluster," Physical Chemistry Chemical Physics, vol. 12, no. 3, pp. 614-620, 2010.

[36] R. L. Parreira, G. F. Caramori, S. E. Galembeck, and F. Huguenin, "The nature of the interactions between $\mathrm{Pt}_{4}$ cluster and the adsorbates $\mathrm{H}, \mathrm{OH}$, and $\mathrm{H}_{2} \mathrm{O}$," Journal of Physical Chemistry A, vol. 112, no. 46, pp. 11731-11743, 2008. 


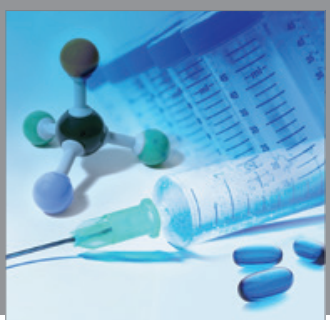

International Journal of

Medicinal Chemistry

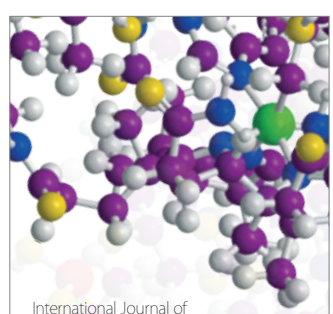

Carbohydrate Chemistry

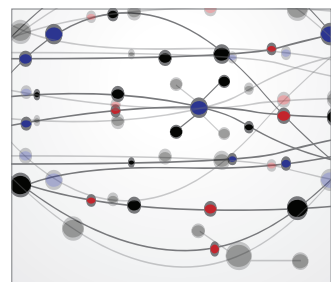

The Scientific World Journal
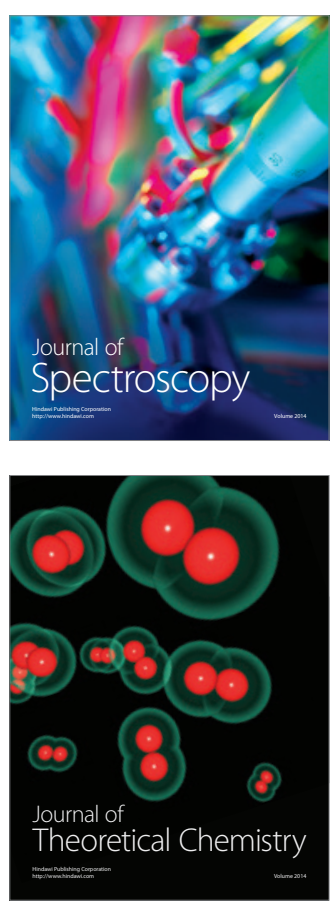
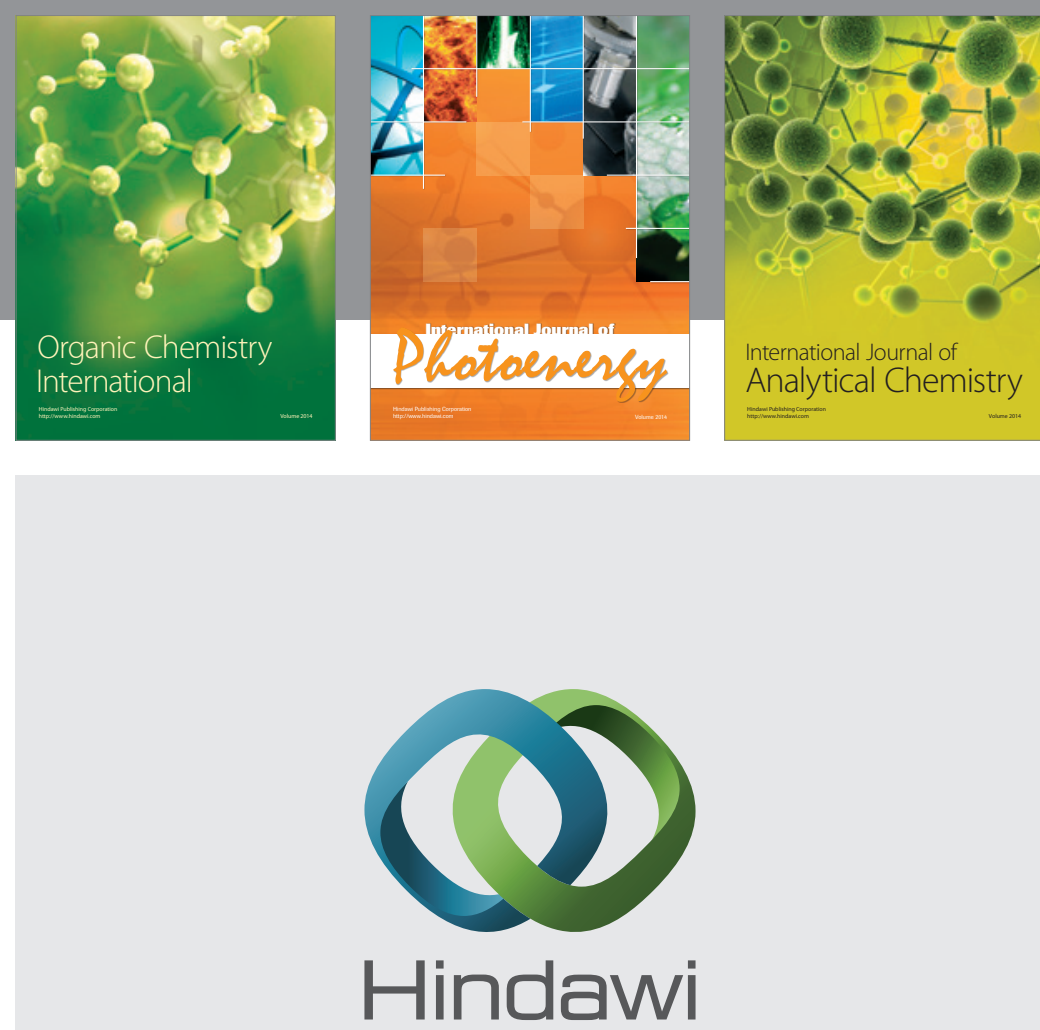

Submit your manuscripts at

http://www.hindawi.com
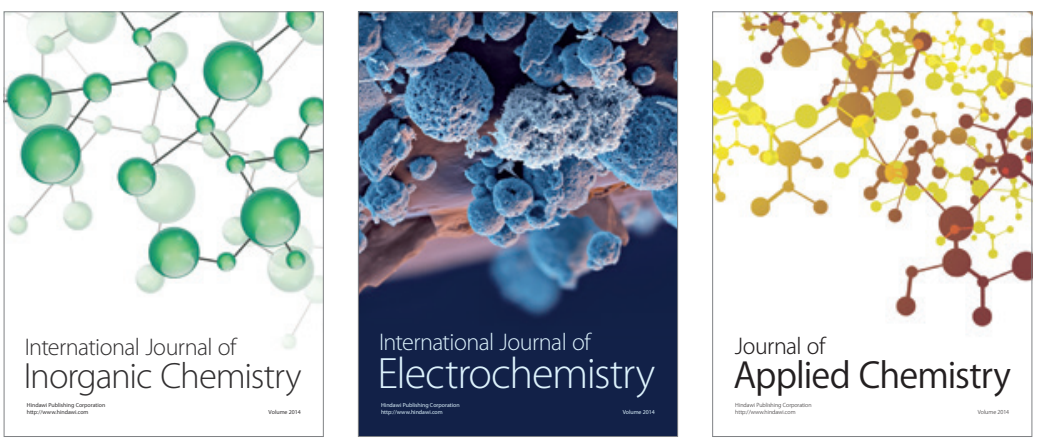

Journal of

Applied Chemistry
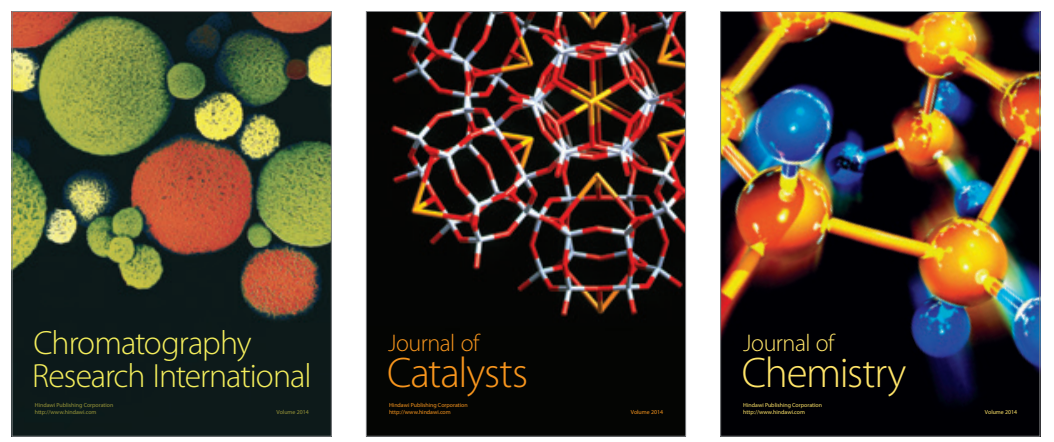
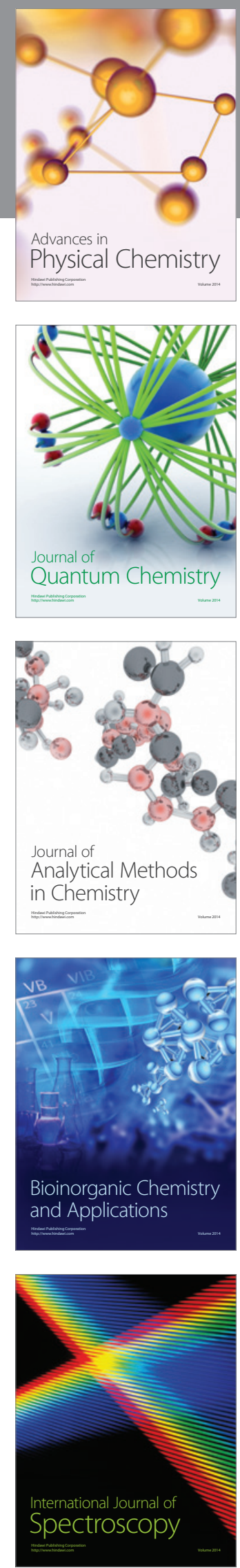